NBER WORKING PAPER SERIES

ECONOMIC FACTORS UNDERLYING THE UNBUNDLING OF ADVERTISING
AGENCY SERVICES

Mohammad Arzaghi

Ernst R. Berndt

James C. Davis

Alvin J. Silk

Working Paper 14345

http://www.nber.org/papers/w14345

\author{
NATIONAL BUREAU OF ECONOMIC RESEARCH \\ 1050 Massachusetts Avenue \\ Cambridge, MA 02138 \\ September 2008
}

An early version of this paper was presented at the NBER Productivity Luncheon Workshop, Cambridge, MA, April 8, 2008. This research was carried out at the U.S. Census Bureau Research Data Center facility at the National Bureau of Economic Research, Cambridge, MA. Research support from the Harvard Business School is gratefully acknowledged. The results and conclusions of the research are those of the authors and do not indicate concurrence by the Census Bureau. These results have been screened to avoid revealing confidential data. The views expressed herein are those of the author(s) and do not necessarily reflect the views of the National Bureau of Economic Research.

NBER working papers are circulated for discussion and comment purposes. They have not been peerreviewed or been subject to the review by the NBER Board of Directors that accompanies official NBER publications.

(C) 2008 by Mohammad Arzaghi, Ernst R. Berndt, James C. Davis, and Alvin J. Silk. All rights reserved. Short sections of text, not to exceed two paragraphs, may be quoted without explicit permission provided that full credit, including $\odot$ notice, is given to the source. 
Economic Factors Underlying the Unbundling of Advertising Agency Services

Mohammad Arzaghi, Ernst R. Berndt, James C. Davis, and Alvin J. Silk

NBER Working Paper No. 14345

September 2008

JEL No. D4,L84,M37

\begin{abstract}
$\underline{\text { ABSTRACT }}$
This paper addresses a longstanding puzzle involving the unbundling of services that has occurred over more than two decades in the U.S. advertising agency industry: How can the shift from the bundling to the unbundling of services be explained and what accounts for the slow pace of change? Using a cost-based theoretical framework of bundling due to Evans and Salinger (2005, 2008), we develop a simple model of an advertising agency's decision to unbundle its services as a tradeoff between the fixed cost to the advertiser of establishing and maintaining a relationship with an advertising agency and pecuniary economies of scale available in providing media services. The results from an econometric analysis of cross-sectional and pooled data collected by the U.S. Census Bureau for quinquennial censuses conducted between 1982 and 2002 support the key predictions of the model. We find that advertising agency establishments are more likely to unbundle if they are large and diversified in their service offerings and are less likely to do so with increasing age and greater geographical scope. We also find a strong trend toward unbundling over time, a result that is partially explained by increases in media prices over time.
\end{abstract}

Mohammad Arzaghi

American University of Sharjah

marzaghi@aus.edu

Ernst R. Berndt

Sloan School of Management

MIT, E52-452

50 Memorial Drive

Cambridge, MA 02142

and NBER

eberndt@mit.edu
James C. Davis

U.S. Census Bureau

jdavis@nber.org

Alvin J. Silk

Graduate School of Business Administration

Harvard University

Soldiers Field

Boston, MA 02163

asilk@hbs.edu 


\section{ECONOMIC FACTORS UNDERLYING THE UNBUNDLING OF ADVERTISING AGENCY SERVICES}

\subsection{INTRODUCTION}

Advertising agencies create advertising campaigns and place advertising messages in media. Over the past three decades, the advertising and marketing services sector has undergone a number of significant changes. In the wake of innovations in information and media technology, deregulation, and globalization, clients have demanded an increasingly array of services (Escobar 2005) as well as greater accountability (Duboff 2007). On the supply side, advertising agencies have both "unbundled" and extended the mix of services they offer (Horsky 2006). Departing from the longstanding industry practice of positioning themselves as "full-service" providers (Pope 1983), agencies have increasingly exhibited a willingness to provide clients with a limited range of services so that now it is not unusual for an advertiser to employ one agency for creative services and another for media services. Paralleling this unbundling, there has been a gradual but fundamental shift in how advertisers compensate agencies (Beals 2007). Whereas agency compensation once consisted almost entirely of commissions related to the amounts clients were billed for purchases of media space and time, reliance on such media commissions has declined over time and now agency income is widely derived from a fee-for-service system based on labor charges for agency personnel working on clients' accounts.

Here we analyze the unbundling of services that has occurred over the period 1982-2002 in the advertising agency industry and consider how this unbundling may be interpreted by the economic theory of bundling. Treating the market for advertising services as contestable (Baumol, Panzar, and Willig 1982), we argue that the Evans and 
Salinger $(2005,2008)$ cost-centered bundling theory provides a framework for modeling the decisions of advertising agencies to choose either a policy of bundling and commission-based agency compensation, or one of unbundling and fee-based compensation. We develop a simple model of an advertising agency's decision to unbundle its services as a tradeoff between the fixed cost to the advertiser of establishing and maintaining a relationship with an advertising agency and pecuniary economies of scale available in providing media services. The results from an econometric analysis of cross-sectional and pooled data collected by the U.S. Census Bureau for quinquennial censuses conducted between 1982 and 2002 support the key predictions of the model. In particular, we find that advertising agency establishments are more likely to unbundle if they are large and diversified in their service offerings, and are less likely to do so with increasing age and greater geographical scope. We also find a strong trend toward unbundling over time, a result that is partially explained by the upward trend in media prices.

The paper is organized as follows. Section 2 outlines the history of bundling and compensation practices in the advertising agency industry. Section 3 summarizes the relevant bundling theory while Section 4 presents a simple model of unbundling of advertising agency services. Section 5 describes the longitudinal database and econometric model we employ to assess empirically the implications of the model. Section 6 presents our empirical results and Section 7 summarizes our conclusions. 
The origins of the modern "full service" advertising agency in the U.S. may be traced back to the middle of the 19th century when "space brokers" first appeared as independent intermediaries in the developing market for newspaper advertising (Pope 1983, Chapter 4). By the turn of the century, U.S. advertisers began to demand additional know-how and services. Pope notes: "The evolution from space broker to advertisement creator to marketing advisor was quite swift" (p. 143) and "between the 1890's and the 1920 's independent agencies became the suppliers of advertising services to virtually all important national advertisers" (p. 147). ${ }^{1}$ This broadening of the scope of agency services meant that the advertisers, rather than the suppliers of media, were the focal clients of advertising agencies. Despite this change and as discussed further below, agencies continued to be compensated primarily on the basis of the volume of media space and time purchased on behalf of advertisers.

Pope emphasizes how a set of institutional arrangements that developed within the industry contributed to the sustained dominance of independent full-service agencies. The "recognition system" as it came to be known, involved an interrelated set of trade practices that Pope characterizes as an "alliance of convenience" between agencies and publishers. The system supported standards relating to the granting of credit and a fixed commission rate (15 percent) by publishers to agencies, and served to dissuade agencies from rebating or splitting commissions with advertisers.

While these practices helped stabilize the advertising business, they also effectively limited advertisers from buying space and time directly from media suppliers, restricted price competition among agencies, and facilitated bundling by independent

\footnotetext{
${ }^{1}$ McFall's (2004, pp. 110-118) study indicates that the development of full service agencies in the U.K. followed a similar path of development.
} 
full-service agencies. Not surprisingly, the recognition system and especially mediabased compensation became the subject of a contentious debate between advertisers on the one hand, and agencies and publishers on the other; this controversy recurred periodically for several decades (Young 1931, Haase 1933, Haase, Lockley, and Diggest 1934, and American Association of Advertising Agencies 1935). On two occasions, federal antitrust authorities undertook investigations of the recognition system on grounds that it constituted a conspiracy in restraint of trade. The first complaint was dismissed in 1930 but the second resulted in the signing of a consent decree in 1956 by several trade associations representing magazine and newspaper publishers and advertising agencies that had been active in establishing industry trade practices for their members (Pope 1983).

One might expect that abandonment of the commission-based agency compensation and the unbundling of advertising services would have followed soon after the signing of the 1956 consent decree that was otherwise credited with effectively dismantling the recognition system (Holland 1981). However, no such rapid transition occurred and by the early 1970's reports in the advertising trade press indicated that bundling and the 15 per cent commission compensation had persisted and were again under attack (Loomis 1972). Clients pressured agencies to unbundle their services and reduce their commissions. Several agencies responded by offering creative and media services on an "a la carte" basis while others resisted this change, provoking a full-scale debate of the merits of alternative policies (Pulver 1979 and Bloede 1983). 
As Pope (1983, p. 116) observed: "Paradoxically, although the functions of the advertising agency have changed almost beyond recognition, the commission method of compensation has survived unending controversy and sporadic campaigns to abolish it." The persistence of media commissions as the dominant mode of agency compensation has long remained a puzzle. Weilbacher (1991, p. 18) summarized industry views of this practice as follows:

No one, as far as is known, has ever been able to justify the commission system in either economic or labor rate terms. The system is simply a classic compromise. As long as they can make a profit, agencies are willing to work for an amount that advertisers are willing to pay, regardless of the amount of actual work involved. Advertisers accept the commission system in the hope that the friction-free environment thus created will lead to a strong and steady stream of advertising ideas.

Thus, advertisers continued to rely on commissions in compensating agencies for another two decades after the 1956 consent decree. Tracking studies conducted by the Association of National Advertisers (ANA) show that as late as 1982, seventy-one percent of the largest U.S. national advertisers surveyed utilized commission-based compensation.

Over the ensuing decade, that share eroded slowly to sixty-one percent in 1994, while labor fee-based compensation grew steadily from eight percent in 1982 to thirtyone percent in 1994. Since then, compensation practices have shifted substantially from commission to labor-based fees, such that as of 2003, only ten percent of large national advertisers reported relying on commissions, while seventy-four percent used fees, and eight percent a combination of commissions and fees (Beals 2007).

The above depiction of changes in agency compensation is incomplete in that it reflects only the behavior of the large national advertisers who constitute the membership of the ANA. Data reported by the Census Bureau covers the sources of 
agency income for the industry as a whole for the period 1977-97, thereby including agencies of all sizes. Table A1 in Appendix A summarizes that information. The major shifts in agency compensation evident from Table A1 are the decline (from 70 to 59 percent) in the share of agency income derived from media commissions and markups on purchases of advertising materials and services accompanied by the increase (from 30 to 41 percent) that occurred between 1992 and 1997 in the shares of income from fees, public relations services, and "other sources". Also noteworthy are the decreases in the commission rate received on media billings and the markup charged on purchases of advertising materials and services from 14 and 16 percent, respectively in 1977 to 11 and 12 percent in 1997. Overall, changes in agency compensation evident in the Census data for the advertising agency industry as a whole are of smaller magnitude but similar with respect to direction and timing relative to those of large national advertisers covered by the ANA studies.

Several factors encouraged advertisers to reconsider their policies on bundling and agency compensation in the post-1970's era. One important development was Gross' (1972) provocative analysis of the allocation of advertising budgets between outlays for the creative development of advertising messages and those for media space and time. Gross argued that underspending on creative development was commonplace and that under the media commission method of agency compensation, advertisers did not directly control the allocation of funds to message development and media exposure. He called for abandonment of both commission-based agency compensation and reliance on fullservice agencies in order to exploit the advantages of diversity by employing multiple independent creative services. By the mid-1990's, several advertisers had adopted the 
latter policy (Dilenschneider 1992, Gleason and Petrecca 1996) and acceptance by both advertisers and agencies of the unbundling of creative and media services steadily grew (Mandese and Wells 1992 and Mandese 1994).

Achenbaum (1990) provides an informed account of other developments affecting advertisers' policies on bundling and agency compensation in the wake of the 1956 consent decree. First, he notes that several agencies introduced compensation arrangements that departed from the traditional 15 percent commission granted by media suppliers to agencies on purchases of space and time made on behalf of their clients. Agencies used these funds to finance other client services, rather than charge clients directly for them. One approach was to provide clients additional services beyond those normally covered by media commissions such as working on new products during their period of development and before media commissions were available (Frey and Davis 1958). Thus, media commissions served to cross-subsidize additional services beyond the traditional ones of creative development and media buying. Profitable accounts also sometimes effectively cross-subsidized unprofitable accounts within the same agency (McDonald 1989). Novel compensation methods included a "cost plus fee" plan from Ogilvy and Mather (Wilson, Hennessy, and Page 1969) and a "profit protection and sharing” arrangement from BBDO (McVeigh 1979).

A second development occurred over the decade 1977-87 when media prices rose annually at rates that substantially exceeded general inflation. As may be seen from Figure1, during that ten year period, the median annual increase in Universal McCann's media unit cost index for national and local advertising was $9.1 \%$ while that for the GDP Implicit Price Deflator was $6.1 \%$. Advertisers perceived agencies to be realizing a profit 
windfall, since the agencies' incomes grew under the commission system with inflated media prices without commensurate increases in their labor efforts or costs (McNamara 1990, pp.144-6). This experience helped fuel advertisers' cost consciousness and demand for reductions in agency compensation, particularly as sales in many product categories matured and prospects for growth appeared dim.

\section{INSERT FIGURE 1 HERE}

A third development that aroused advertisers' displeasure with agency finances was the wave of mergers that began in the mid-1980's (Millman 1988). Many clients were surprised at the sale prices and personal enrichment of agency top executives. Moreover, the mergers and acquisitions often violated client conflict norms and policies and disrupted the morale of agency personnel while offering few apparent benefits to clients.

Overall, these developments appear consistent with the timing of changes in compensation and bundling policies discussed above. Whereas the bundling of agency services occurred rapidly in the early stages of the U.S. advertising industry, unbundling is a more recent phenomenon that has evolved only gradually. Not surprisingly, agency bundling and compensation practices are highly interdependent and reflect the structure of vertical market relations among advertisers, agencies, and media suppliers.

\subsection{Agency Economics and Industry Organization}

Demand for advertising services in the U.S. tends to be cyclical (Blank 1962) and arises from two distinct segments: national advertisers and local advertisers (primarily 
retailers). ${ }^{2}$ Client-agency relations are notoriously asymmetric with respect to their relative power, consistent with the substantial observed rate at which clients switch agencies (American Association of Advertising Agencies 1997).

The advertising services business has long been recognized as a highly competitive industry, consisting of a large population of agencies of widely varying sizes. Silk and King (2008) calculated several measures of concentration in the advertising agency industry from published Census data for the period 1977-2002. While the level of concentration rose in 1997 and 2002, the size distribution of firms and establishments continued to be highly diverse, with the Herfindahl-Hirschman Index (HHI) for firms and establishments in 2002 being only 195 and 10, respectively. ${ }^{3}$ The latter are well below the threshold value HHI=1,000 used by the Department of Justice and the Federal Trade Commission to delineate between "unconcentrated" and "moderately concentrated" industries. ${ }^{4}$ Small agencies have continued to play a major role as indicated by the 2002 Economic Census which reported that single unit firms accounted for 96.4 percent of all firms (NAICS 54181), 41.7 percent of total industry receipts, and 47.4 percent of total industry employment. ${ }^{5}$

Analyzing data for the period 1972-87, Jung and Seldon (1995) conducted a test for market power using the method developed by Bresnahan (1982) and found the

\footnotetext{
${ }^{2}$ National advertising accounted for 55 percent of total U.S. advertising in 1977 and 61 percent in 2002. See Table 1 in Silk and King (2008) for trends in several indicators of demand for agency services and advertising in the U.S. over the period, 1977-2002.

${ }^{3}$ Several large mergers and acquisitions involving holding companies occurred in the 1990's and are a likely source of the rise in concentration .For further discussion, see King, Silk, and Ketelhohn (2003). ${ }^{4}$ See: U.S. Department of Justice and Federal Trade Commission, "Horizontal Merger Guidelines," Revised April 8, 1997. Accessed at: http://www.usdoj.gov. The maximum possible value of the HerfindahlHirschman Index is 10,000.

${ }^{5}$ U.S. Bureau of Census, Establishment and Firm Size 2002, Economic Census, Professional, Scientific, and Technical Services Subject Series, November 2005, Table 3, p. 104.
} 
estimated index of market power to be small and not significantly different from zero. Finally, it bears noting that over the last half century, the advertising agency business in the U.S. has become more geographically dispersed, spreading west and south from its original base in the corridor running from New York through Philadelphia to Chicago (King, Silk, and Ketelhohn 2003).

Within this industry, barriers to entry are minimal, fixed costs are low, and payroll-related expenses account for two-thirds to three-quarters of agency costs. Arzaghi (2005a) examined entry and exit rates calculated from U.S. census data for 1977-2002 and found that on average, a single unit agency remained in business for about seven years; over a five-year period, the birth rate was more than 50 percent. Arzaghi (2005b) has also shown that informal networks are a pervasive feature of this industry and the resulting spillover effects are an especially important influence on agency growth. Thus entry and exit barriers appear to be largely absent, a condition manifest in the substantial mobility agency personnel exhibit over the course of their careers, moving to and from client organizations as well as between agencies (Broschak 2004).

Consistent with the industry characteristics discussed above, cross sectional studies of agency cost data (Schmalensee, Silk, and Bojanek 1983, Silk and Berndt 1993) that treat agencies as multiproduct firms (Bailey and Friedlaender 1982) indicate that scale and scope economies are empirically significant. Silk and Berndt (1993) found that of the approximately 10,000 firms comprising the industry in 1987 , only $200-250$ agencies had domestic gross incomes as large or larger than the estimated minimum efficient size of a U.S. advertising agency. Thus the industry can be characterized as a 
zero-profit contestable one with price equal to average cost, rather than a perfectly competitive one with price equal to marginal cost.

A special feature of the advertising agency industry is its longstanding adherence to the norm that a single agency should not service competing clients in the same business category (American Association of Advertising Agencies 1979). As will be discussed in Section 4.2,2, this phenomenon, commonly referred to as "conflict policy" has an important bearing on the effects of bundling by full-service agencies (Silk and Berndt 1994) and the growth and diversification of holding companies in the advertising and marketing services industry (Silk and Berndt 2004).

\subsection{BUNDLING AND TYING THEORY}

We now briefly survey the economic literature on bundling and tying, paying particular attention to the small part of the literature that addresses bundling in highly competitive markets, or more precisely in perfectly contestable markets. In line with the evidence discussed above, we suggest that the assumption of perfectly contestability is a reasonable approximation of competition in the advertising services industry.

The existing economic literature on bundling focuses primarily on situations where firms have considerable market power. This emphasis arises because bundling becomes more important and less transparent when used as a device for increasing economic profits by leveraging market power from one product to another or by using price or quantity of the second good as a means of effectively price discriminating in the primary market where the seller has market power. The implications of these considerations are important for industrial organization economics and regulatory policies. While the former, tying, is an anticompetitive practice prohibited by law, the 
latter, price discrimination, is not necessarily considered predatory behavior and may even increase market efficiency (Varian 1989).

Thus, the principal concern of the economic literature on bundling and tying has been to specify the conditions under which the effects of bundling may be anticompetitive rather than price discriminatory. In general, the conclusion reached is that there is no reason a firm with a monopoly for one product would also wish to bundle a complementary competitive product (Director and Levi 1956, Posner 1979, Schmalensee 1982, and Winston 1990). Rather, the literature focuses primarily on how tying arrangements can be viewed in a context apart from an extension of monopoly power or foreclosure in the tied good market and turns to price discrimination as the main motivation for tying (Burnstein 1960, Stigler 1968, Adams and Yellen 1976, Schmalensee 1984, McAfee, McMillan and Winston 1989). ${ }^{6}$ Other reasons for tying have been suggested, such as economies of scale and scope and risk management (Palfery 1983). Here again, the models typically have been concerned with explaining tying by firms that can exercise considerable market power.

Surprisingly, even though bundling (and tying) may occur for such straightforward reasons as achieving cost savings in packaging and marketing, compatibility of components, and scale economies in producing complementary goods, those aspects of bundling have received relatively little attention. ${ }^{7}$ These considerations

\footnotetext{
${ }^{6}$ However, recent work shows that under more complex assumptions and circumstances, a monopolist can extend its monopoly power to other markets. Whinston (1990) has shown that tying can indeed increase monopoly power and profitability when the tied market is characterized by economies of scale and imperfect competition. Carlton and Waldman (2002) have demonstrated that when dynamic models are considered, the monopolist can use tying and foreclosure to deter the entry of efficient firms into its primary market or newly emerging markets. Spector (2007) shows that tying and bundling can facilitate collusion when the market for the tied complementary good is oligopolistic.

${ }^{7}$ The exceptions include Baron and Besanko (1992, 1999), Gilbert and Riordon (1995), Salinger (1995), and Evans and Salinger $(2005,2008)$.
} 
can, however, explain the most common cases of bundling, especially bundling in competitive markets such as the bundling of electronic goods and batteries, and eyeglass frames and lenses.

The lack of attention to cost savings or efficiency increases in research on bundling appears to be due to the view that the underlying incentives are unimportant and/or that significant efficiency losses do not arise. Even in Davis and Murphy (2000) who consider the welfare increasing aspects of bundling in the case of highly complementary software, the firms involved are assumed to have significant market power as monopolists or duopolists.

By contrast, in this study of the highly competitive advertising services industry, our focus is on cost savings or efficiency increases that may arise from unbundling and how changes in the input costs of the bundled services can change these savings and thus bundling practices. More specifically, our interest here is in explaining the fundamental structural shift in bundling and compensation practices that has occurred in the U.S. advertising services industry over the past three decades.

\subsection{A COST-BASED MODEL OF BUNDLING AND UNBUNDLING OF ADVERTISING AGENCY SERVICES}

We now develop a simple cost-based model of an advertising agency's decision to bundle or unbundle its services. We simplify this decision by treating an advertising campaign as consisting of two complementary service components, (i) creative (development and production of advertising messages) and (ii) media (planning and buying media space and time in media vehicles to disseminate advertising messages to target markets). The model captures the fundamental characteristics of advertising agency 
economics and, as we will document in Section 6, helps to explain the observed shift from bundling to unbundling of these services over the past three decades.

\subsection{Theoretical Framework}

As a framework for the present study, we adopt the cost-based theory developed by Evans and Salinger $(2005,2008)$ to explain bundling in competitive markets. Evans and Salinger show how cost savings from bundling and preferences for different components determine the choice among unbundling, mixed bundling, and pure bundling in contestable markets. They conclude that pure bundling is the likely outcome when the fixed costs of distinct product offerings are large and/or when demand for the individual components is insufficient to make it profitable to offering them separately,

In the case of advertising services, both the creative and media components are required to produce an advertising campaign. Thus, differential demand for components is not an issue here. Rather, the tradeoff is between the savings in fixed and variable costs that an advertiser may realize by purchasing both creative and media services from a single full-service agency as opposed to purchasing each service separately from two specialized agencies. In other words, our analysis evaluates whether and when the bundling or the unbundling of creative and media services results in more efficient production. We show that when external circumstances change, bundling may fall out of favor with advertisers.

Given that scale economies affect the costs of creative and media inputs required to produce an advertising campaign, if the input price for one of the tied service components (say, media) in the bundled services increases rapidly, an advertiser may find it less costly to employ separate suppliers for creative and media services. While 
additional costs may be incurred in selecting, coordinating, and monitoring the specialized suppliers, the advertiser may find that the total cost of a campaign is lower when produced by two separate specialized services as compared to that associated with employing a single, full-service agency. Such a differential in total costs may arise as a result of differences in the extent to which economies of scale in media services can be realized under conditions of unbundling versus unbundling. We discuss the cost advantage of specialized media services over full-service agencies below in section 4.2.2.

The only prior study known to the present authors that has addressed the bundling of advertising services is that due to Horsky (2006). She models an advertiser's decision to select bundled or unbundled advertising services, including the choice between inhouse and outsourced suppliers. In a cross-sectional analysis, she finds that advertisers with large advertising budgets unbundle to take advantage of media discounts obtained by specialized media services.

The present model resembles Horsky's formulation in that it partitions an advertising campaign into complementary creative and media components and recognizes that ultimately, it is the advertiser who chooses between bundled or unbundled advertising campaigns. Our model differs from Horsky (2006) however, in several key assumptions and implications. First, we focus on the behavior of advertising agencies rather than advertisers. Second, we investigate the effect on advertising agency structure and specialization of increases in media prices relative to other advertising costs (Figure 1). The model implies that advertising agencies react differently to this exogenous change depending on the scale of their media services. Thus we endogenize the advertising agency's choice of its compensation methods and internal organizational structure, which 
depend on input prices and transaction costs. Third, our analysis yields empirically testable predictions pertaining to how changes in an advertising agency's compensation methods are related to changes in media prices and the scale of an agency's media services operations.

\subsection{Basic Assumptions of the Model}

We outline a static model where a cost comparison by the advertiser determines the choice between a bundled and an unbundled advertising campaign for a given account. We simplify the components of an advertising campaign into creative and media services. Under bundling, the full-service advertising agency supplies both creative and media services, but is compensated solely by commissions on media billings. In the unbundling scenario, one agency provides the creative services and directly charges fees for those services, while a second agency performs the media function and is separately compensated for those services. The model rests on two key assumptions: (1) perfect contestability; and (2) the presence of scale and scope economies in the production of advertising campaigns. We discuss each assumption below.

\subsubsection{Perfect Contestability}

We assume that the market for an advertising campaign is perfectly contestable (Baumol, Panzar, and Willig 1988). The assumption of perfect contestability is consistent with salient characteristics of the advertising services industry discussed in Section 2.2, especially, asymmetric agency-client relations, minimal entry and exit barriers, high turnover, small minimum efficient agency size, the persistence of a highly diverse size structure, and demand from heterogeneous clients consisting of national and local advertisers operating in geographically dispersed locations. It may further be noted that 
Silk and Berndt (1994) argued that the advertising agency industry conforms to the conditions MacDonald and Slavinsky (1987) showed were required for a competitive industry with free entry to sustain an equilibrium with multiproduct firms. ${ }^{8}$

Collectively, these conditions imply that an advertising agency will provide any combination of the services (bundled, unbundled, or mixed) that an advertiser prefers at the agency's minimum total costs. ${ }^{9}$ Thus, the bundling decision depends on what arrangement is cost-preferred by the advertiser. The total costs of an advertising campaign paid by an advertiser includes the coordination and information costs of dealing with agencies, costs for services (creative, production, and media planning and placement) directly charged to the client by the agencies, plus the net cost of media space and time and other advertising materials and services purchased by the agency and billed to the client. To identify the conditions that make unbundling the dominant strategy, we calculate the total cost of an advertising account under "bundled" and "unbundled" scenarios, and compare the two costs.

\subsubsection{Scale and Scope Economies}

The model relies critically on economies of scale and scope in the production of advertising campaigns. Economies of scope are captured by the benefits of dealing with a single full-service agency for all advertising services that lower information, search, monitoring, and coordination costs. In contrast, additional costs arise from addressing principal-agent problems (Spake, D'souza, Crutchfield, and Morgan 1999) when

\footnotetext{
${ }^{8}$ See MacDonald and Slavinsky (1987, footnote 1) for a brief discussion of the relationship of their model to that of Baumol, Panzar, and Willig 1988) on contestable markets. See Eaton and Lemeche (1991) for a generalization of the Mac Donald and Slavinsky model.

${ }^{9}$ For simplicity, we exclusively model costs of delivering an advertising campaign. Clearly, any efficiency gain in production can be interpreted as a reduction in the overall costs and can be included in the total cost function.
} 
employing two or more specialized agencies rather than a single full-service agency. The fixed (informational) costs of initiating and monitoring relations with a second agency a media services agency — combined with the costs of coordinating activity with a separate agency performing creative services can be avoided if the advertiser employs a single full-service advertising agency to handle both components of a campaign. ${ }^{10}$

However, the benefits of working with a full-service agency may come at a higher cost of service provision. Thus, the determining factor in advertiser's choice between bundling and unbundling is the tradeoff between the differences in fixed costs and variable costs associated with employing separate specialized agencies for creative and media services rather than a single full-service agency for both services.

There are two distinguishable types of scale economies that arise in this context: (a) pecuniary economies realized as a result of the availability of volume discounts from media suppliers and the bargaining power and negotiating skills of the media buyer; ${ }^{11}$ and (b) non-pecuniary economies that result from fuller utilization of lumpy resources used in media planning and buying such as research, decision-support systems, and specialized personnel (Drexler 2002).

As noted in Section 2.2, empirical evidence supporting the presence of scale and scope economies in the overall operations of full-service agencies has been found in previous studies (Schmalensee, Silk, and Bojanek 1983, Silk and Berndt 1993). However,

\footnotetext{
${ }^{10}$ These fixed (informational) costs are essential to making bundling a viable choice (Evans and Salinger, 2005).

${ }^{11}$ It has been suggested that over time, the advantage in media prices obtained by media services over fullservice agencies has diminished (Anderson 1999 and Reinhard 2001).
} 
the evolution of the advertising services industry indicates that specialized media agencies have an advantage over full-service agencies in capturing size-related economies relating to purchase of media services.

The early specialized media services were independent firms who first established a significant position in the U.S. market in the late 1980's, a time when advertisers' media options were proliferating. These firms promised cost savings and efficiency gains in media buying (especially for spot television and radio) beyond those available from full-service agencies (Goldring 1986) —advantages arising from their ability to pool demands from numerous advertisers and leveraging their negotiating skills and relationships with media suppliers as well as their investments in research and systems (Rigg 1990).

Initially a large share of the revenues obtained by independent media services came from small and medium-sized full-service agencies who found it uneconomical to operate their own internal media groups and turned to outsourcing of this function (Pfaff 1987, Mandese 1994). Full-service agencies responded to the competition from independent media services in several ways. Some unbundled their media services, spinning the media units off as separate profit centers and actively pursuing media-only accounts (Mandese and Wells 1992). Other agencies established customized media units, dedicated to a particular client in order to address client concerns about conflict policy (Mandese 1995)

Viewing the full-service agency as a multiproduct firm when an agency's mix of services is defined in terms of the set of different media used in the campaigns it produces, Silk and Berndt (1994) hypothesized that bundling by full-service agencies in 
combination with the restrictions on agency growth imposed by the norm of not serving competing accounts, induces agencies to diversify their media mixes more extensively than would otherwise be cost justified. Product categories or industries differ in the use of alternative media. A pair of firms competing in the same industry is more likely to use similar mixes of media than is a pair of firms operating in different industries. If an agency could serve a competitor of an existing client, it could exploit scope economies with respect to mix of media used in that industry. However, since serving competing accounts is customarily prohibited, an agency seeking to grow must add a client in a different industry and adjust it media mix accordingly. This implies that under the strictures imposed by compliance with client conflict norms, the larger the size of a fullservice agency, the more likely it is to expand its mix media beyond that which is strictly cost justified. Silk and Berndt (1994) estimated media-specific scale and scope economies for a cross-section of full-service agencies and found that for each of nine media categories, substantial numbers of large agencies operated with diseconomies of scope. In line with the hypothesis of "excessive" diversification, media-specific scope economies were shown to be negatively related to full-service agency size.

Over time, agency-client relations have evolved in ways that have led to modifications in industry norms on serving competing accounts and enabled specialized media services to gain an advantage over full-service agencies with respect to capturing pecuniary and non-pecuniary economies related to media services. The preeminent development has been the growth and success of global holding companies. Through aggressive pursuit of globalization and diversification, holding companies attained double-digit growth rates during the 1990's, accomplished to a considerable degree by 
completion of hundreds of mergers and acquisitions. ${ }^{12}$. The holding company concept was first introduced as a means of circumventing the longstanding industry norm that prohibits an advertising agency from serving competitors in the same market. After finding that the major holding companies all realized positive scope economies through diversification of either lines of business or market coverage, Silk and Berndt (2004) suggested that the sub-optimal excessive diversification imposed on full-service agencies as a result of bundling and conflict policy had been obviated by the holding company form of organization.

Large multi-brand advertisers seeking cost savings and other benefits have consolidated their media buying across brands and markets with specialized media services, especially those that are members of holding companies (Fine et al. 2005, pp. 60-63). As media options continued to expand, client demand for specialized capabilities offered by media services with respect to negotiating expertise, media research, measurement of effectiveness, and optimization has also grown. At the same time, several waves of mergers and acquisitions have reduced the number of options available to clients, particularly those seeking a consistent global presence. In this changed environment, clients have exhibited greater willingness to relax somewhat their demands for exclusivity (Sampey 2005) and holding companies have found ways to alleviate client concerns about violating traditional norms relating serving competing accounts, such as by structuring several separate agency networks within the same holding company (Chura and Wentz 2004). In 2007, the four leading holding companies owned 13 of the 15 largest media agencies operating in the U.S. Nonetheless, issues of exclusivity

${ }^{12}$ As public corporations, holding companies enjoy access to external capital markets, an advantage over independent agencies that, with rare exceptions, have remained privately held (Von Nordenflycht 2005). 
continue to arise (Fitzgerald 2004) and can lead to shifts of major media buying accounts among media agencies (Neff 2005).

The availability of size-related economies in media planning and buying is consistent with the level of concentration in this sector (NAICS 54183). The concentration ratios for 4, 8, and 20 largest of the nearly 900 firms comprising this sector in 2002 accounted for 30, 39, and 50 percent of total sector income, respectively (Silk and King 2008, Table 4). National advertisers tend to be the principal clients served by large media planning and buying services, with the purchasing of local media for local advertisers remaining the domain of small and medium-sized full-service or in-house agencies (Mandese 2002). Major advertisers are reported to pay fees equivalent to 1 to 2 percent of media spending for media services (Johnson 2005). ${ }^{13}$

\subsection{Advertising Agency Production Function and Costs}

In this section we introduce an underlying production function for an advertising campaign that captures the key feature of complementary between the creative and media components of an advertising campaign. The quantity of creative services, $V$ generates advertisements designed for a specific medium (e.g. a commercial to be run on television). The quantity of media space and time, $W$ (measured by the size of the audience reached and the frequency of their exposure to a campaign) is purchased based on a schedule for the placement of advertisements. We assume that both inputs $V$ and $W$ are essential (strictly positive) in producing $Y$, an advertising campaign, which, in turn, is measured as the number of quality adjusted messages delivered to some target audience over a given time period. We assume the technology relating $\mathrm{V}, W$, and $Y$ is Leontief

\footnotetext{
${ }^{13}$ For some evidence on how media service compensation varies by medium and by the size of client advertising expenditures, see Beals (2007, pp. 27-31 and 52-54).
} 
fixed-coefficient. The quality dimension of creative services is captured by a multiplicative term $Q_{c}$, a production function shifter reflecting the effectiveness of the advertising messages (Gross, 1972). Thus, the production function for an advertising campaign is:

$$
Y=Q_{c} \operatorname{Min}\{\alpha W, \beta V\}
$$

where $\alpha$ and $\beta$ are fixed input-output coefficients. Without loss of generality, we assume that creative services and media space are scaled such that both fixed coefficients equal unity. Specifically, with this normalization, for any non-zero prices of creative services and media space, the optimal (cost minimizing) combination of inputs must satisfy:

$$
W=V
$$

On the cost side, we assume volume price discounts, $d_{M}$, are offered by media suppliers on purchases of advertising space and time as a non-decreasing function of the total quantity of space and time, $M$ made by the full-service advertising agency or the media services agency on behalf of clients. ${ }^{14}$ This captures pecuniary economies of scale in media buying activities. If the advertiser buys creative and media services from a multiproduct (full-service) advertising agency, the above production function represents the advertising agency's production function for the account. Otherwise the advertiser purchases each component separately at the service provider's average cost (since markets are perfectly contestable), and uses the above technology to produce an advertising campaign. The total variable production costs of this unbundled approach are:

$$
T=T_{c}+T_{m}+\left(1-d_{M}\right) P_{m} W
$$

where $T_{c}$ is the cost of creative services, $T_{m}$ the cost of media services, and

\footnotetext{
${ }^{14}$ In other words, $M=\Sigma \mathrm{W}$ for the agency.
} 
$\left(1-d_{M}\right) P_{m} W$ is the discounted cost of media space and time (passed through from media suppliers).

There are two distinct aspects of scale economies. On the production side, the variable costs of media services are given by: $T_{m}=\delta P_{m} W$ where $\delta(0<\delta<1)$ is a fixed share of media expenditure volume. The costs of creative services, $T_{c}=P_{c} Q_{c} V$, include the price of creative services, $P_{c}$, applied to a quality adjusted quantity of services, $Q_{c} V$.

Given our normalization in (2), without loss of generality, this reduces to:

$$
T=\left(P_{c} Q_{c}+\delta+\left(1-d_{M}\right) P_{m}\right) W
$$

Note that any fixed costs of initiating and maintaining contacts with agencies and possible coordination costs paid by the advertiser from working with multiple agencies are not included in the above variable cost function. We address those cost elements below.

We assume that specialized media buying agencies can capture greater pecuniary and non-pecuniary economies of scale in media services than can full-service agencies. As was discussed earlier in Section 4.2, this advantage arises from the specialized media service provider's ability to consolidate the media buying activities of more and/or larger accounts and thereby achieve greater scale with respect to media services than can comparable independent full service advertising agencies whose media volume is constrained by the number and size of clients it provides with both creative and media services.

\subsection{Bundling Scenario}

In this case, the advertiser pays the fixed information costs (costs of searching for an agency, learning about it, and initiating and maintaining the relationship) for an 
advertising campaign (account), which we denote as $T_{r}$. The advertising agency

purchases the media space, $m$, on behalf of the advertiser for the account at the (net of the commissions) price $\left(1-d_{M}\right) P_{m}$. Given the above variable production cost function, the total cost to the advertiser is:

$$
T_{B}=T_{r}+\left(P_{c} Q_{c}+\delta+\left(1-d_{M}\right) P_{m}\right) W
$$

The commission on media purchases, $r\left(1-d_{M}\right) P_{m} W$ compensates the agency for both the creative and media services it provides. We note that this rate, $r$, is not the traditional commission rate defined in the industry, rather it is the "capitalized commission" rate. The capitalized commission rate (r) is closely related to the wellknown media commission rate $\left(\mathrm{r}_{\mathrm{m}}\right)$, per the following monotonic relationship:

$$
r=\frac{r_{m}}{1-r_{m}}
$$

For example, for the traditional media commission rate of 15 percent, the capitalized rate is $.15 / .85$ or 17.6 percent. In our context, the capitalized media commission rate turns out to be: $:^{15}$

$$
r=\frac{P_{c} Q_{c}+\delta}{\left(1-d_{M}\right) P_{m}}
$$

As expected, $r$ increases with increases in the quality of creative services, $Q_{c}$; the price of creative services, $P_{c}$ (from an increase in wages); the unit cost of media operations, $\delta$; with decreases in the media price discount, $d_{M}$ (the volume discount is smaller when the total media buying volume of the agency, $M$, is smaller); and with a decrease in the price of media space or time, $P_{m}$.

\footnotetext{
${ }^{15}$ The underlying assumption is that the advertising agency market is contestable and thus there should not be an economic profit. Revenue would only cover costs.
} 


\subsection{Unbundling}

The production technology of an advertising campaign is the same as in the bundled scenario. The advertiser must bear higher information costs to establish and organize relationships with separate media buying and creative agencies. In addition, an advertiser may incur coordination and integration costs for purchasing the two complementary inputs to an advertising campaign from separate firms. We capture these additional unbundling costs by assuming that the advertiser must duplicate the fixed information costs to purchase from two firms, $2 T_{r}$, as compared to the bundling case with only one input supplier. ${ }^{16}$ The advertiser also needs to pay for creative services separately, $T_{c}$. In return, the advertiser can benefit from a lower unit variable cost for its media space and time purchases. That is, specialized media buying agencies can aggregate volume and bargain more effectively for lower prices (higher discounts) from media suppliers, and also have lower overhead costs for media buying operations (in general, larger pecuniary economies of scale in media activities). Hence, the specialized media service can exploit scale economies to the fullest such that $d_{M^{\prime}} \geq d_{M}$ and likely that $\delta \leq \delta^{\prime}$. Thus, the total costs to the advertiser facing the unbundled agency are:

$$
T_{U}=2 T_{r}+\left(P_{c} Q_{c}+\delta^{\prime}+\left(1-d_{M^{\prime}}\right) P_{m}\right) W
$$

The capitalized media commission rate charged by media buying agencies turns out to

be:

\footnotetext{
${ }^{16}$ Our analysis and results would not change qualitatively as long as the fixed information costs in the unbundling scenario are larger than in the bundling scenario. The fixed cost saving is the necessary condition for bundling ever to occur, regardless of the values of other parameters in the model (Evans and Salinger 2005). One can interpret the information cost, or the cost of establishing a relationship for a campaign with an agency, as the search cost for finding an adequate match. In that case, the advertiser pays the search costs once in the bundling scenario, and twice in the unbundling scenario, but it will attain a better overall match in the unbundling situation (i.e., better price for media buying activities). With some manipulation, this would qualitatively provide a very similar model.
} 


$$
r^{\prime}=\frac{\delta^{\prime}}{\left(1-d_{M^{\prime}}\right) P_{m}} .
$$

\subsection{Advertiser Choice}

The advertiser's choice of bundled or unbundled services depends on which scenario minimizes total costs, given that advertising agency profits are driven to zero due to contestable market competition. Bundling is preferred if $T_{B}$ in (5) is less than $T_{U}$ in (8), i.e., if:

$$
\left(\delta-\delta^{\prime}+\left(d_{M^{\prime}}-d_{M}\right) P_{m}\right) W<T_{r}
$$

If we assume that the only benefit of consolidating media buying activities is an increase in the purchase discounts for media ${ }^{17}, \delta=\delta^{\prime}$, i.e. that the variable cost of media buying production is the same within a specialized media buying agency compared to a full service agency, , then the condition for bundling to occur becomes

$$
\left(d_{M^{\prime}}-d_{M}\right) P_{m} W<T_{r}
$$

Notice that if the price of media space increases rapidly, other things equal, this tips the balance toward unbundling. That is, as long as there are pecuniary economies of scale in consolidating media buying activities, then $d_{M^{\prime}}>d_{M}$ and increases in the price of media space and time raises the left-hand side of the inequality (11). Comparative static analyses demonstrate that the tendency toward unbundling increases when the price of media space or time increases $\left(P_{m}\right)$ results in failure of the inequality $(11)$, when economies of scale for media services increase $\left(d_{M^{\prime}}\right.$ becomes increasingly larger than $d_{M}$ ), the size of the client's advertising campaign is larger ( $W$ is larger), and when the agency is smaller ( $d_{M}$ is lower for smaller agencies). Finally, a smaller fixed

\footnotetext{
${ }^{17}$ In this way, without loss of generality, we simplify the notation.
} 
information cost, $T_{r}$, of establishing a working relationship with an agency for an account will also result in a tendency toward unbundling.

\subsection{Econometric Model Specification}

As developed in the previous section, the decision to award an advertising campaign to a full-service agency (bundling) or to buy the components separately (unbundling) is based on the inequality in equation (11), wherein a binary choice decision is formulated. If the condition is satisfied, then the advertising agency's cost structure is such that the advertiser's optimal decision is to purchase creative and media services from the same agency.

For purposes of estimation we would ideally have access to data at the level of individual accounts (advertising campaigns) and the agencies serving those accounts. However, the data available to us are at the agency establishment level where we are unable to observe prices and volumes for individual client campaign accounts. We assume client decisions relating to their choices of full-service agencies are exogenous with respect to their bundling decisions. Heterogeneity in accounts and client characteristics will generate a mixture of bundled and unbundled accounts within a given advertising agency. We therefore aggregate client bundling decisions into a measure of the share of an agency establishment's total revenue arising from unbundled services. Specifically, within advertising agencies, when a positive share of accounts is bundled, agency compensation for both creative and media buying services is derived from the percentage commission taken on the volume of media billing. (See Eq. (15) in Section 5.2 below). In the case of unbundled accounts, clients are charged fees for creative and media services. Thus, the share of agency revenue derived from fees represents a measure of the extent to which an agency has unbundled its services. (See Eq. (16) in Section 5.2 
below). Since we estimate the model at the agency establishment level, any variation in decisions at the account level not captured by agency characteristics (such as scale and scope variables) are absorbed into the error structure

We assume the supply of media services is a competitive activity, where media service establishments are sized optimally to maximize economies of scale and capture available discounts, $d_{M}$. Thus, given inequality (11), ceteris paribus, the odds that accounts at full-service advertising agencies will be bundled is related to their ability to compete with specialized media services, as indicated by how close $d_{M}$ is to $d_{m}$. If the full service agency has a large media billing volume (large pecuniary economies of scale), its accounts are more likely to be bundled. Small agencies are less likely to be able to realize the economies of scale required to offer competitive bundling agreements and hence are more likely unbundle to unbundle, leaving their clients to employ the services of a specialized media services provider.

We further expect that increases in media prices, $P_{m}$ (compared to other agency expenses (e.g., wage costs) magnify differences in media buying discounts and force even large agencies to unbundle. In other words, the threshold level of media size for full-service agencies to be competitive with specialized media services agencies increases as media prices rise, and thus the cutoff point in size distribution of full-service agency media purchases (M) for providing bundled services increases (i.e., shifts to the right). Controlling for advertising agency characteristics, including size, we therefore hypothesize that the share of an advertising agency's revenue from unbundled activities (i.e., from fee-based compensation rather than media commissions) is negatively related to the interaction term, $d_{M} P_{m}$. 
Our econometric specification for the share of agency $i$ 's total revenue at time $t$ obtained from fee-based and other direct compensation is given by:

$$
\operatorname{shunb}_{i t}=\beta \mathbf{x}_{i t}+\left(\gamma_{0}+\gamma_{1} M_{i t}\right) P_{m t}+\eta_{t}+\varepsilon_{i t}
$$

where $\mathbf{x}_{i t}$ is a vector of advertising agency characteristics, including advertising agency establishment size, scope, age, media billings, holding company affiliation, and number of establishments in the parent firm. Time dummies $\eta_{t}$ control for overall shifts in market conditions over time, such as changes in media suppliers' discount schedules, and election year/Olympic year demand surges. Although we expect positive effects from changes in media prices over time via the product, $\gamma_{0} P_{m t}$, any variation in media prices and the terms of the media buying alternative that are common to all advertising agencies are absorbed in the time indicators.

From inequality (11), we expect the relationship of price and the share of fees in equation (12) to be positive, where $\gamma_{0}$ is large and positive, and $\gamma_{1}$ is negative, such that $\left(\gamma_{0}+\gamma_{1} M_{i t}\right)$ will be smaller in absolute terms for advertising agency establishments with higher media billings. Larger agencies are less responsive to changes in media prices, as they can offer similar volume discount rates to those available from most specialized media service providers. The shift toward unbundling is therefore expected to be stronger and occur earlier for smaller agencies as the price of media space and time increases relative to other costs because they are less able to offer volume discounts comparable to those available from specialized media buying services. Equation (12) can be rewritten as:

$$
\operatorname{shunb}_{i t}=\beta \mathbf{x}_{i t}+\gamma_{1} M_{i t} P_{m t}+\eta_{t}+\varepsilon_{i t} .
$$


The interaction term represents the key predictions of our model, namely that: (i) increases in media prices have given rise to unbundling by advertising agencies; and (ii) that this effect has occurred sooner for smaller agencies.

Thus, the model presented above yields predictions relating to the emergence of specialized media services organization that has occurred over the past three decades. In this model we have endogenized the decisions of advertising agencies. This implies that agencies will unbundle creative and media services in response to large increases in media prices. In the competitive environment of this industry, full-service agencies had little choice but to abandon bundling practices and separate their media services operations.

A second prediction from the model is that over time, as media prices increase relative to other (mostly wage-based) services, a shift to unbundling should occur first for full-service agencies with smaller media services volume, since full-service agencies with larger scale could initially achieve the same level of scale economies available to specialized media services. However, given the advantage of specialized media services discussed in Section 4.2.2 with respect to capturing pecuniary and/or non-pecuniary economies, they would eventually surpass the scale of media buying by full-service agencies, forcing them to unbundle.

\subsection{DATABASE AND ESTIMATION}

\subsection{Data Sources and Cross-Sectional Samples}

The establishment level data for advertising agencies are from the U.S. Census Bureau's Economic Census of Service Industries (CSR) covering the period 1977 - 2002 
at five year intervals. The data are a census of all private employers. Our universe includes all active advertising agency establishments in the continental U.S. with positive employment and payroll for Standard Industrial Classification (SIC) code 7311, Advertising Agencies censuses conducted between 1977 and 1992, and North American Industrial Classification System (NAICS) code 54181, Advertising Agencies from 1997 onward. ${ }^{18}$ As shown in Table A1, the number of establishments (with payroll) grew from 8,089 in 1977 to a peak of 13,879 in 1992, and declined modestly to 13,390 in 1997.

Advertising media price data are prepared by Robert Coen, Universal McCann, and are available from his office. The Universal McCann Media Cost Indices measure the year-to-year changes in media unit costs, in relation to the period 1982-1984. We use the "composite media unit index for national and local advertising budgets," as reported by Universal McCann in August, 2007. Elements of the composite include advertisements in newspaper, magazine, network television, cable television, spot television, network radio, spot radio and direct mail.

Our interest is in the unbundling of advertising functions performed by agencies, which limits estimation to smaller samples that report all the data required to do so. Attrition may occur for several reasons. Table A2 shows these sample sizes to vary between 1,225 for 2002 and 5,064 for 1992. The Census Bureau mails questionnaires to all establishments that belong to firms with two or more establishments (multi-unit firms), all single-unit employers with payroll above a cutoff, and to a stratified sample of small single-unit employers. The payroll cutoffs vary by detailed kind of business. For

\footnotetext{
${ }^{18}$ The Census Bureau converted the Economic Census from the SIC to the NAICS industry classification system in 1997. SIC 7311 maps into NAICS 54181 directly.
} 
example in 2002, the payroll cutoffs were defined at the eight digit NAICS product code level, and for services industries ranged from a total firm payroll of $\$ 15,000$ to $\$ 1,000,000$ (Hovland and Gauthier 2006). ${ }^{19}$ After including multi-unit and large singleunit firms with certainty, Census selected an approximate $9.5 \%$ stratified sample of the remaining small single-unit firms. Data for single unit firms in the non-mail universe are taken from administrative records of other federal agencies. In addition, of the mail universe, "long form" detailed questions on sources of sales receipts are sent to a subset of establishments. For example, in 1997 the long questionnaire was sent to a little over half of service establishments, and the short questionnaire to the remainder. Due to sample construction, a significant share of item non-response occurs for industry specific questions on media billings and advertising agency fees (sources of receipts). We return to a discussion of potential selection issues due to item non-response in Section 5.3 below.

\subsection{Variable Definitions}

Our basic specification from equation (13) is:

$$
\begin{gathered}
\operatorname{SHUNB}_{i t}=\alpha+\beta_{1} \cdot \operatorname{LINC}_{i t}+\beta_{2} \cdot S C P S_{i t}+\beta_{3} \cdot \operatorname{LEST}_{i t}+\beta_{4} \cdot H C D_{i t}+\beta_{5} \cdot L A G E_{i t}+\beta_{6} \cdot S U D_{i t} \\
-\gamma_{1} \cdot L M B L_{i t} \cdot M P I_{t}+\eta_{t}+\varepsilon_{i t}
\end{gathered}
$$

As was pointed out in Section 2.1, the unbundling of advertising agency services has been accompanied by a shift in how advertisers compensate agencies from commissions and markups on purchases of media, materials, and other services used in

\footnotetext{
${ }^{19}$ A one million payroll might appear large. However, at an average annual salary of $\$ 25,000$ per worker, this would result in firms with 40 or more employees being included in the certainty sample. For the 1997 census, the cutoff for services was defined so as to include single-unit firms with ten or more employees in the certainty sample. In the 1992 census, the cutoff included single-unit firms with more than 3 employees.
} 
the production of advertising campaigns, to fees related to charges for labor utilized in providing agency services. Table A1 shows the shares of agency revenue derived from three sources: (a) commissions on media billings, (b) markups on purchases of advertising materials and services, and (c) fees for services for various census years. ${ }^{20}$ We combine the first two components (a plus b) and define "share of income from bundled services" as:

SHUNB $_{\text {it }}=($ commissions on media + markups on materials and services $) /($ revenue $)$

We then define the dependent variable in Eq. (14), shunb $b_{\mathrm{it}}$ as the share of establishment i's revenue at time $t$ contributed by fees for creative and other services, such as public relations, where:

$$
\operatorname{SHUNB}_{i t}=1-\operatorname{SHBUN}_{i t}
$$

Note from Table A1 that the share of agency income arising from fees almost doubled between 1987 and 1997, growing from 23 percent to 41 percent while that from commissions and markups declined commensurately.

Eq. (14) includes as explanatory variables a vector of advertising agency characteristics, as defined in Table 1.

\section{INSERT TABLE 1 HERE}

Advertising establishment revenue and media billings are collected directly by questionnaires. Revenue is the establishment's operating income, including commissions

\footnotetext{
${ }^{20}$ For most years, commissions on media and agency income on materials and services are reported directly on questionnaires. For 2002, these were calculated as billings minus costs, which presented some data availability and consistency issues that resulted in a smaller sample size for that year.
} 
and services fees. Gross media billings include both commissions to the advertising agency establishment and the much larger pass-through payments to media companies for advertising space and time.

Our scope variable is constructed as a count of activities performed within the establishment. The number of services reported has expanded over time; in 1977 and 1982 there were five categories on the questionnaire, in 1997 fifteen, and in 2002 as many as twenty. Our measure of scope was limited to four elements available in all years of the questionnaire. These are listed in Table 1.

The Census Bureau routinely sends the Company Organization Survey to firms to collect information on ownership, specifically, to update its listings of establishments for which a firm owns a greater than $50 \%$ share. This is the Census definition of a firm, or enterprise, often called the alpha in the data. Data exploration revealed that most advertising agencies generally retain their own EIN federal tax ID. As a result, we have three tiers of ownership structure in the data. The alpha is equivalent to the holding company, where the holding company may be comprised of one or more agencies. The EIN is equivalent to the agency, where agencies may be comprised of one or more establishments. We define a holding company dummy variable HCD, which identifies all establishments that are member of a multi-agency (multi EIN) holding company firm (alpha). LEST is the natural log of the count of the advertising agency establishments affiliated with a firm. Firms operating at one establishment location are indicated as single unit firms by a dummy variable SUD.

The Longitudinal Business Database (LBD) follows advertising establishments over time. Considerable effort was invested in the LBD to recover longitudinal identifiers 
for establishments through linking records and matching names and addresses (Jarmin and Miranda 2002). The first year when data for the Census establishment business register were available to construct the LBD was 1975; hence, the establishment age data are truncated at that year. Advertising establishments born prior to 1975 are indicated by a dummy variable BDD. The LBD includes the birth year as the first year the establishment entered the business register, which we use to calculate establishment age.

\subsection{Sample and Pooling Issues}

\subsubsection{Sample Selection}

As noted in section 5.1, the samples used in estimation were between $13 \%$ and $43 \%$ of the population of advertising agency establishments within a given year. We investigate the possibility of sample selection bias in our results, where sources of nonrandom sample selection in our context could be based on sampling procedures, survey non-response and/or incidental truncation. The majority of reductions that occurred in the preparation of estimating samples were the result of exogenous sample selection, establishments that were simply not sent the long version of the questionnaire by design. Economic Census selection criteria were based on establishment payroll, with large establishments or firms being more likely to receive the long form. We seek to verify that the random sampling of smaller establishments provides sufficient response coverage so as not to bias our estimates. Of greater potential concern would be either non-response for questions used to construct the dependent variable shun $b_{\text {it }}$, or incidental truncation. For example, if some advertising agencies do not offer media buying services, they would not propose a bundled contract to an advertiser and thus would not be 
expected to report media commissions. If this selection is related to unobserved factors, it might be endogenous.

Due to differences in Census sampling strategies and the large variation in sample sizes by year, we separately estimate yearly selection equations. We include explanatory variables from the model in equation (14) of log sales, log within-firm advertising establishment counts, and indicators for single-unit status and holding company ownership. We include additional variables described below that are not included in the share model. Thus we do not rely on the nonlinearity of the first stage selection equation for our corrected estimates, but instead rely on exclusionary restrictions for identification in the second stage share model.

In the first stage we include additional size controls of establishment annual payroll and employment. These size measures capture the criteria used by Census for sample design. Also included are location contextual measures, specifically an indicator for rural location, and a count of other advertising agencies in the city. Advertising establishments located in cities with many neighbor advertising establishments are more likely to specialize locally, network with other agencies, outsource and/or in the case of multi-establishment firms, to distribute work across facilities. Legal form of organization (LFO) indicator variables are added for sole proprietorship, partnership, and corporation, where other is the residual category. LFO could affect non-response, since different legal corporate structures are associated with different accounting requirements that could affect the extent and quality of internal information collection. We have no reason to expect LFO to have an independent effect on the propensity of an agency to offer a bundled contract. 
We estimated Heckman $(1976,1979)$ selection models for each year, and in almost all cases found that the inverse Mills ratio terms in the second stage estimates were insignificant. The only exception was for 2002, the year for which our estimating sample was smallest. Comparing corrected and uncorrected 2002 coefficient magnitudes revealed few differences. In all years, we found no meaningful differences in the slope coefficient estimates when compared to the non-corrected estimates. Moreover, most first stage coefficients were significant with the expected sign. Larger establishments and firms were more likely to be in the sample as expected. Rural agencies were less likely to offer media buying services, and advertising establishments located in cities with large advertising agglomerations were more likely to return surveys that included some item non-response. Results for LFO were not consistent across years or robust. We conclude that the substantial observed item non-response does not bias our results.

We are not aware of another study that has reported sample selection results using Census establishment-based micro data. Our results offer an example of the advantage of using the very large universe samples of establishments available in the Economic Census. The characteristics of the estimating sample can be compared to the complete population of firms and establishments.

\subsection{2 .Inter-temporal Stability of Slope Coefficients}

In the construction of our pooled panel estimates, we were interested in the extent to which slope coefficients might vary over time. First, we ran yearly cross sectional models separately, and found that our estimates are robust across years. We ran further tests of differences in coefficients across adjacent census years by pooling pairs of years and including a full set of second year interaction terms. In general, we found differences 
for coefficients across years were statistically insignificant. One exception was for the scope measure, a result that was expected. The scope of activities performed by advertising establishments has been changing over time, as shown in Figure 2 and discussed in the next section. Based on these tests, results are also included in Section 6 for a version of the share equation where the regression coefficients for our scope measure can vary over time.

A second exception was for 1977. There were three issues with the 1977 equation year. First, the wording of the questionnaire was such that advertising establishments were asked for media billings as part of receipts. This issue was addressed differently and more satisfactorily in the 1982 questionnaire. Second, the slope coefficients were clearly and statistically significantly different for this year compared to later years, due to the differences in measurement. Finally, our measure for establishment age was problematic because there were an insufficient number of years since 1975 to construct a meaningful measure. Due to these issues, we excluded the 1977 equation year from our panel estimates. However, we have retained 1977 data in the graphs and tables of descriptive statistics.

The high turnover rate among agency establishments precluded use of panel analysis to capture establishment fixed effects. Only $15 \%$ of observations in our samples are for establishments that appear in the dataset for three or more periods.

\subsection{RESULTS}

6.1 Pooled Regression Results: 1982-2002 
Figure 2 documents the trends in the mean share of agency income (unweighted and weighted by agency income) derived from unbundled services for the five crosssectional samples of agencies spanning the period 1977 to 2002 . Focusing on the weighted mean series, we observe that the mean unbundling share was under 13 percent in 1977, grew steadily reaching 23 percent in 1987, then rose more rapidly to 45 percent in 1997 before flattening out at approximately 44 percent in 2002.

\section{INSERT Figure 2 HERE}

To investigate the determinants of the growth in unbundling share, we pooled the data for the five cross-sections collected in the censuses for 1982 to 2002 and estimated a set of seven alternative model specifications, the results of which are presented in Table

2. With only a few exceptions noted below, the estimated coefficients are relatively stable across specifications with respect to expected sign and statistical significance.

\section{INSERT Table 2 HERE}

To capture changes over time in the level of unbundling share, we included dummy variables for each census from 1987 through 2002 (D1987,..D2002), with 1982 serving as the base year and included in the intercept term. The estimated coefficients for these four dummy variables are positive and significantly different from zero $(\mathrm{p}<.001)$ across all five models in which they were included, the sole exception being in model 7 where the estimated coefficient for the 1987 dummy variable is negative but insignificant. The pattern of growth in unbundling share indicated by the magnitude of the estimated coefficients for the census year dummy variables is one of increases from 1987 onward, with a leveling off in 2002. 
As a further check on cross-sectional differences, we interacted the SCPS variable with the census year dummy variables in two model specifications. The results are shown in Columns (6) and (7) of Table 2. The estimates of the interaction effects followed a consistent pattern across both models: positive and statistically significant $(\mathrm{p}<.001$ level) for 1987 and 1992; negative and significant $(\mathrm{p}<.001)$ for 1997; and positive, but not significant for 2002. We now turn to a discussion of results relating to the predictions developed from our theoretical model and other variables of interest.

\subsubsection{Media Price, Agency Media Billings and their Interaction}

As discussed in Sections 4.7 and 4.8, our theoretical model of unbundling yields predictions about the effects of media prices, agency media billings, and their interaction on the share of agency revenue accounted for by unbundled services. Referring to Table 2, we find that our measure of unit media prices (MPI) is positively and significantly ( $p$ $<.001)$ related to the unbundling share in both specifications (model 2 and model 4) where it appears. The log of media billings (LMBL) is negatively related to unbundling share in all four specifications where it is included, with all four of the estimated coefficients significant $(\mathrm{p}<.001)$. Thus, as expected, the greater the volume of media placed by an agency, the less its reliance on income from unbundled services.

Finally, as predicted, the estimated coefficient for the interaction of LMBL and MPI is negative in all six relevant specifications and is statistically significant $(p<.001)$ in five of them.

Overall then, our results provide consistent support for the predictions developed from our theoretical model. Increases in media prices encourage input cost-reducing unbundling by an agency. On the other hand, the greater the volume of media placed by 
an agency, the less its reliance on income from unbundled services, where the size of this latter effect depends upon the level of media prices.

\subsubsection{Agency Scale and Scope}

The share of agency income from unbundled services increases with increases in agency size (LINC) $)^{21}$ Across all seven specifications, the estimated coefficients for each of these regressors have the same positive sign and are statistically significant $(p<.001)$.

Two variables capture the effects of the number of establishments comprising an agency: the dummy variable SGUD contrasts single and multiunit agencies while LEST (logarithm of the number of establishments within an agency) measures the influence of size variations in multiunit agencies. The estimated coefficients for SGUD are negative, indicating single unit agencies tend to have lower unbundling share than multiunit agencies, but the effect is imprecisely measured, being statistically significant at the .05 level in only four of the seven specifications. Conversely, unbundled share decreases as the log of number of establishments (LEST) comprising an agency increases. Controlling for sales, this suggests greater geographical scope goes hand in hand with the operation of advertising agency establishments having a greater bundled share of operating income. This effect appears to be reliably measured across specifications as all seven coefficients for LEST are negative and significant $(\mathrm{p}<.001)$.

\subsubsection{Holding Company Affiliation and Agency Age}

We expect holding company structure to increase the scope of affiliated establishments. The estimated coefficients for the dummy variable representing affiliation

\footnotetext{
${ }^{21}$ The positive relationship between agency size and unbundling is consistent with Horsky's (2006) finding that the likelihood of an advertiser unbundling increases with the size of its advertising budget.
} 
with a holding company (HCD) are consistently positive but significantly so in only three of the seven specifications $(\mathrm{p}<.05)$.

The effects of agency age are measured by two variables. The dummy variable BRDD distinguishes between agencies that began operations before $(=1)$ versus after $1975(=0)$. The estimates of the coefficient for BRDD indicate a negative relationship of agency age with unbundling share, but the estimated coefficients are not significantly different from zero $(p>.10)$ for six of seven specifications. However, when measured by the log of agency age (LAGE, defined as the log of the difference between a given census year and 1975), the effects of agency age are also found to be negative, indicating that the longer an agency had operated, the lower the share of its income from unbundled services. For LAGE, the estimated coefficients were all negative and significant (.05 level or beyond) for six of the seven specifications. An implication is that, other things equal, older surviving advertising agencies are more likely to cling to bundling, whereas the younger and newer entrants are more likely to specialize and unbundle.

To facilitate comparisons as to the relative magnitude of the effects of the regressors, we report the standardized regression coefficients (Wooldridge 2000) in column $5 \mathrm{~b}$ of Table 2 . The standardized regression coefficients (SRC) answer the question: How many standard deviations does the dependent variable unbundling share (SHUNB) change when the regressor increases by one standard deviation? We see from Table 2 that that the scale and scope variables have the largest positive effects on SHUNB, the SRC's being .398 and .295 for LINC and SCPS, respectively. LMBL (log media billings) and the interaction of LMBL and MPI (media prices) have the largest 
negative effects, their SRC's being -.349 and -.201, respectively. None of the other explanatory variables in model (5) has a SRC greater than 0.10 .

\subsection{Scope Model}

One possible specification issue is whether the SCPS variable, the number of distinct product groups (range 1-4) for which the establishment receives revenues, is jointly determined with the unbundling share, thereby potentially generating a simultaneous equations bias in the unbundling share equation. On a priori grounds, we believe any such simultaneity is much more likely to be present at the level of a firm, but not at the establishment level. It is of course possible that as an establishment becomes unbundled, it becomes more specialized, reducing the scope of its product offerings. Hence the sensitivity of our principal findings in the unbundled share equation to such a specification issue is an empirical issue. Unweighted means of the SCPS variable generally declined over time between the 1977 and 2002 Census, having values of 3.19, $3.03,3.01,2.82,2.74$, and 2.88, suggesting that at the establishment level, product scope declined as the unbundling share increased, implying possible increased specialization.

We have addressed this specification issue by deleting the SCPS variable from the unbundled share equation, and then estimating an additional equation with SCPS as the dependent variable, having the same set of regressors as the unbundled share equation with ScopeN2 deleted. This two equation system can be interpreted as a set of reduced form equations. We estimate the SCPS equation (with dependent variable 1, 2, 3 or 4) using ordered probit estimation methods. We then assess the extent to which our principal findings in the preferred unbundled share equation model are sensitive to deletion of the SCPS variable. Results of our analysis are presented in Table 3. 


\section{INSERT TABLE 3 HERE}

As is seen in the first two columns of Table 3, parameter estimates for the unbundled share equation (Column 1) are not only qualitatively unaffected by exclusion of the SCPS variable (Column 2), they are also quantitatively very similar. This provides us with assurance that our principal findings are robust to a possible simultaneous equation estimation bias involving SCPS.

Nonetheless, it is of interest to examine the parameter estimates in the ordered probit equation. Note that since our dependent variable can take on only four values, coefficient estimates indicate how changes in a regressor affect the probability of moving from 1 to 2 and from 3 to 4, but not from 2 to 3 . See Greene (2003, pp. 736-740) for further discussion. With this caveat in mind, we present in Column (3) of Table 3 parameter estimates from the ordered probit equation. As is seen there, probabilities of moving from 1 to 2 products, and from 3 to 4 products, increase with sales, and decrease with number of establishments in the unit, media billings, price and over time (i.e., the magnitudes of the negative coefficients for the yearly dummy variables tends to increase from 1987 to 2001).

It bears noting that the signs of these estimated coefficients in the SCPS equation (Column 3) parallel those in the unbundled share equation (Column 2), with the coefficient for HCD being negative and significant in the Scope model while negative but non-significant in the unbundling share regression. Thus, controlling for time trends, these results indicate that across our sample of full-service agencies, agency establishments within holding companies specialize and unbundle while other agency establishments unbundle by increasing their scope. 


\subsection{CONCLUSIONS}

In this research we have addressed a longstanding puzzle concerning the unbundling of services that has occurred over more than two decades in the advertising agency industry: How can the shift from the bundling to the unbundling of services be explained, and what accounts for the slow pace of change? Using the Evans and Salinger $(2005,2008)$ cost-based theory of bundling as a framework, we have developed a simple model of an advertising agency's decision to unbundle its services. Empirical support for the key predictions of the model have been obtained from an econometric analysis of pooled longitudinal data for the period 1982-2002. More specifically, our results show that advertising agency establishments are more likely to unbundle if they are large and diversified in their service offerings and are less likely to do so with increasing age and greater geographical scope. A strong trend toward unbundling over time is evident, a result that is partially explained by the substantial increases in media prices that occurred over the period studied.

The unbundling of advertising agency services investigated in this study evolved gradually over a long period of more than two decades and was accompanied by a continuing stream of criticism maintaining that unbundling led to a decoupling of creative and media services that sacrificed valuable synergies between the two functions (Drexler 2002). Interestingly, the advertising industry is presently in the early stages of a major transition from its longstanding reliance on mass media to an era when new communications technologies will play an increasingly important role. With the onslaught of numerous novel communications options, demand for closer integration of creative and media services has heightened and led to calls for "re-bundling" (Reinhard 
2002, Sawyer 2008). Holding companies have expanded their digital marketing capabilities via numerous acquisitions. Recently, they have begun to re-organize their media agencies with digital operations and other capabilities (branding and creative services) so as to position themselves as offering broader "marketing solutions" beyond media planning and buying (McClellan 2008).

Technological changes bring not only new means of reaching consumers but also new tools for managing campaigns (Evans 2008). As these developments unfold and their effects on media, creative, and production costs come into sharper focus, an important task for future research will be to assess the viability of new bundling strategies.

Interpreted through the lens of the model presented here, this complexity might increase the fixed costs of creating agency-client relationships as well as create greater inter-media competition with the introduction of new communication technologies, thereby exerting downward pressure on media prices. More broadly, these developments are likely to affect advertising agency service offerings and their underlying governance structure. The dynamics of firm and industry structure promises to continue to be an interesting topic for future study. 
Table 1

VARIABLE DEFINITIONS AND SUMMARY STATISTICS

(Pooled Sample for 5 Cross sections, 1982-2002, $n=14,491$ )

\begin{tabular}{|l|l|l|l|}
\hline $\begin{array}{l}\text { Variable } \\
\text { Name }\end{array}$ & Mean & $\begin{array}{l}\text { Standard } \\
\text { Deviation }\end{array}$ & Description \\
\hline SHUNB & .323 & .330 & $\begin{array}{l}\text { Unbundled (non-commission compensation) share } \\
\text { of total agency establishment operating income }\end{array}$ \\
\hline LINC & 6.106 & 1.620 & $\begin{array}{l}\text { Log of agency establishment operating income } \\
\text { (current \$ thousands) }\end{array}$ \\
\hline SCPS & 2.899 & 1.045 & $\begin{array}{l}\text { Number of major services offered by the } \\
\text { establishment (range: } 1-4) \text {, consisting of a total } \\
\text { count from (i) media buying, (ii) purchases of } \\
\text { advertising materials and services, (iii) creative } \\
\text { services, and (iv) other services, including public } \\
\text { relations and marketing research. }\end{array}$ \\
\hline LEST & .385 & 1.000 & $\begin{array}{l}\text { Log of the number of advertising establishments in } \\
\text { the firm }\end{array}$ \\
\hline HCD & .104 & .305 & $\begin{array}{l}\text { Holding company ownership; dummy variable: } \\
\text { 1=holding company ownership, 0=otherwise. }\end{array}$ \\
\hline LAGE & 1.938 & .819 & $\begin{array}{l}\text { Log of establishment age: census year - age of } \\
\text { birth, where 1975 is the earliest year of birth } \\
\text { (censored distribution). }\end{array}$ \\
\hline BRDD & .273 & .446 & $\begin{array}{l}\text { Dummy variable denoting establishment birth date: } \\
\text { 1=born before 1975; 0=otherwise }\end{array}$ \\
\hline SGUD & .783 & .412 & $\begin{array}{l}\text { Single-unit agency; dummy variable: 1=single- } \\
\text { unit; 0=multi-unit }\end{array}$ \\
\hline LMBL & 6.790 & 2.092 & $\begin{array}{l}\text { Log of establishment gross media billings (current } \\
\text { \$ thousands) }\end{array}$ \\
\hline MPI & .957 & .220 & $\begin{array}{l}\text { Media unit price index (Universal McCann) for } \\
\text { national and local budgets }\end{array}$ \\
\hline Interaction term: LMBL x MPI \\
\hline
\end{tabular}


Table 2

POOLED UNBUNDLING SHARE REGRESSIONS:

1982, 1987, 1992, 1997, \& 2002

( $n=14,491)$

Estimated Regression Coefficient / (Robust Std, Error)

Model

\begin{tabular}{|c|c|c|c|c|c|c|c|c|}
\hline Variable & 1 & 2 & 3 & 4 & $5 \mathrm{a}$ & $5 b^{*}$ & 6 & 7 \\
\hline Intercept & $\begin{array}{l}-.007 \\
(.015)\end{array}$ & $\begin{array}{l}-.745^{\mathrm{d}} \\
(.017)\end{array}$ & $\begin{array}{l}-.197^{\mathrm{d}} \\
(.014)\end{array}$ & $\begin{array}{l}-.347^{\mathrm{d}} \\
(.041)\end{array}$ & $\begin{array}{l}-.065^{\mathrm{d}} \\
(.019)\end{array}$ & na & $\begin{array}{l}-.139^{\mathrm{d}} \\
(.019)\end{array}$ & $\begin{array}{l}.022 \\
(.017)\end{array}$ \\
\hline LINC & $\begin{array}{r}082^{d} \\
(.003)\end{array}$ & $\begin{array}{c}.066^{\mathrm{d}} \\
(.003)\end{array}$ & $\begin{array}{c}.074^{d} \\
(.003)\end{array}$ & $\begin{array}{c}.075^{\mathrm{d}} \\
(.003)\end{array}$ & $\begin{array}{l}.081^{d} \\
(.003)\end{array}$ & .398 & $\begin{array}{r}.076^{\mathrm{d}} \\
(.003)\end{array}$ & $\begin{array}{l}.084^{\mathrm{d}} \\
(.003)\end{array}$ \\
\hline SGUD & $\begin{array}{l}-.021^{\mathrm{b}} \\
(.009)\end{array}$ & $\begin{array}{l}-.012 \\
(.009)\end{array}$ & $\begin{array}{l}-.012 \\
(.009)\end{array}$ & $\begin{array}{l}-.020^{\mathrm{b}} \\
(.009)\end{array}$ & $\begin{array}{l}-.018^{\mathrm{b}} \\
(.009)\end{array}$ & -.023 & $\begin{array}{l}-.014 \\
(.009)\end{array}$ & $\begin{array}{l}-.020^{c} \\
(.009)\end{array}$ \\
\hline SCPS & $\begin{array}{l}.093^{\mathrm{d}} \\
(.002)\end{array}$ & $\begin{array}{l}.096^{\mathrm{d}} \\
(.002)\end{array}$ & $\begin{array}{l}.095^{\mathrm{d}} \\
(.002)\end{array}$ & $\begin{array}{l}.095^{\mathrm{d}} \\
(.002)\end{array}$ & $\begin{array}{l}.093^{\mathrm{d}} \\
(.002)\end{array}$ & .295 & $\begin{array}{l}.074^{\mathrm{d}} \\
(.002)\end{array}$ & $\begin{array}{l}.075^{\mathrm{d}} \\
(.002)\end{array}$ \\
\hline LEST & $\begin{array}{l}-.031^{\mathrm{d}} \\
(.004)\end{array}$ & $\begin{array}{l}-.022^{\mathrm{d}} \\
(.004)\end{array}$ & $\begin{array}{l}-.027^{\mathrm{d}} \\
(.004)\end{array}$ & $\begin{array}{l}-.025^{\mathrm{d}} \\
(.004)\end{array}$ & $\begin{array}{l}-.029^{\mathrm{d}} \\
(.004)\end{array}$ & -.088 & $\begin{array}{l}-.029^{\mathrm{d}} \\
(.004)\end{array}$ & $\begin{array}{l}-.031^{\mathrm{d}} \\
(.004)\end{array}$ \\
\hline HCD & $\begin{array}{l}.023^{\mathrm{b}} \\
(.012)\end{array}$ & $\begin{array}{l}.009 \\
(.012)\end{array}$ & $\begin{array}{c}.014 \\
(.012)\end{array}$ & $\begin{array}{c}.017 \\
(.012) \\
\end{array}$ & $\begin{array}{r}.020^{\mathrm{b}} \\
(.012)\end{array}$ & .019 & $\begin{array}{c}.019 \\
(.012) \\
\end{array}$ & $\begin{array}{l}.024^{\mathrm{b}} \\
(.011)\end{array}$ \\
\hline LAGE & $\begin{array}{l}-.011^{\mathrm{c}} \\
(.004)\end{array}$ & $\begin{array}{l}-.014^{\mathrm{d}} \\
(.004)\end{array}$ & $\begin{array}{l}-.009^{b} \\
(.004)\end{array}$ & $\begin{array}{l}-.014^{\mathrm{d}} \\
(.004)\end{array}$ & $\begin{array}{l}-.010^{b} \\
(.004)\end{array}$ & -.025 & $\begin{array}{l}-.009^{b} \\
(.004)\end{array}$ & $\begin{array}{l}-.010^{c} \\
(.004)\end{array}$ \\
\hline BRDD & $\begin{array}{l}-.004 \\
(.006)\end{array}$ & $\begin{array}{l}-.005 \\
(.006)\end{array}$ & $\begin{array}{l}-.010^{\mathrm{d}} \\
(.006)\end{array}$ & $\begin{array}{l}-.001 \\
(.006)\end{array}$ & $\begin{array}{l}-.006 \\
(.006)\end{array}$ & -.088 & $\begin{array}{l}-.009 \\
(.006)\end{array}$ & $\begin{array}{l}-.005 \\
(.006)\end{array}$ \\
\hline D1987 & $\begin{array}{l}.083^{\mathrm{d}} \\
(.005)\end{array}$ & & $\begin{array}{l}.197^{\mathrm{d}} \\
(.006)\end{array}$ & & $\begin{array}{l}.119^{d} \\
(.011)\end{array}$ & na & $\begin{array}{l}.057^{\mathrm{d}} \\
(.012)\end{array}$ & $\begin{array}{l}.003 \\
(.014)\end{array}$ \\
\hline D1992 & $\begin{array}{l}.141^{\mathrm{d}} \\
(.006)\end{array}$ & & $\begin{array}{c}.328^{\mathrm{d}} \\
(.008)\end{array}$ & & $\begin{array}{c}.200^{\mathrm{d}} \\
(.016)\end{array}$ & na & $\begin{array}{r}.226^{\mathrm{d}} \\
(.015)\end{array}$ & $\begin{array}{l}.115^{\mathrm{d}} \\
(020)\end{array}$ \\
\hline D1997 & $\begin{array}{l}.343^{\mathrm{d}} \\
(.010)\end{array}$ & & $\begin{array}{c}.662^{\mathrm{d}} \\
(.014)\end{array}$ & & $\begin{array}{c}.446^{\mathrm{d}} \\
(.029)\end{array}$ & na & $\begin{array}{r}.780^{\mathrm{d}} \\
(.029)\end{array}$ & $\begin{array}{l}.585^{\mathrm{d}} \\
(.038)\end{array}$ \\
\hline D2002 & $\begin{array}{l}.242^{\mathrm{d}} \\
(.011)\end{array}$ & & $\begin{array}{c}.642^{\mathrm{d}} \\
(.015)\end{array}$ & & $\begin{array}{c}.369^{\mathrm{d}} \\
(.035)\end{array}$ & na & $\begin{array}{c}.598^{\mathrm{d}} \\
(.040)\end{array}$ & $\begin{array}{l}.337^{\mathrm{d}} \\
(.052)\end{array}$ \\
\hline SCPS*D1987 & & & & & & & $\begin{array}{l}.047^{\mathrm{d}} \\
(.004)\end{array}$ & $\begin{array}{l}.042^{\mathrm{d}} \\
(.004)\end{array}$ \\
\hline SCPS*D1992 & & & & & & & $\begin{array}{l}.036^{\mathrm{d}} \\
(.004)\end{array}$ & $\begin{array}{l}.033^{\mathrm{d}} \\
(.004)\end{array}$ \\
\hline SCPS*D1997 & & & & & & & $\begin{array}{l}-.042^{\mathrm{d}} \\
(.008)\end{array}$ & $\begin{array}{l}-.045^{\mathrm{d}} \\
(.008)\end{array}$ \\
\hline SCPS*D2002 & & & & & & & $\begin{array}{c}.017 \\
(.012)\end{array}$ & $\begin{array}{l}.018 \\
(.012) \\
\end{array}$ \\
\hline LMBL & $\begin{array}{l}-.078^{\mathrm{d}} \\
(.002)\end{array}$ & & & $\begin{array}{l}-.062^{\mathrm{d}} \\
(.006)\end{array}$ & $\begin{array}{l}-.055^{\mathrm{d}} \\
(.006)\end{array}$ & -.349 & & $\begin{array}{l}-.052^{\mathrm{d}} \\
(.006)\end{array}$ \\
\hline MPI & & $\begin{array}{c}.881^{\mathrm{d}} \\
(.018)\end{array}$ & & $\begin{array}{l}.485^{\mathrm{d}} \\
(.043)\end{array}$ & & & & \\
\hline MPI*LMBL & & $\begin{array}{l}-.063^{\mathrm{d}} \\
(.002)\end{array}$ & $\begin{array}{l}-.072^{\mathrm{d}} \\
(.002)\end{array}$ & $\begin{array}{l}.008 \\
(.006)\end{array}$ & $\begin{array}{l}-.023^{\mathrm{d}} \\
(.006)\end{array}$ & -.201 & $\begin{array}{l}-.074^{\mathrm{d}} \\
(.002)\end{array}$ & $\begin{array}{l}-.028^{\mathrm{d}} \\
(.006)\end{array}$ \\
\hline SEE & .272 & .276 & .272 & .275 & .271 & & .270 & .270 \\
\hline $\mathrm{R}^{2}$ (adj.) & .321 & .301 & .318 & .306 & .321 & & .327 & .330 \\
\hline
\end{tabular}

${ }^{\mathrm{a}} \mathrm{p} .<.10,{ }^{\mathrm{b}} \mathrm{p}<. .05,{ }^{\mathrm{c}} \mathrm{p}<.01,{ }^{\mathrm{d}} \mathrm{p}<.001$

${ }^{*}$ Standardized regression coefficients for model $5 \mathrm{a}$. 
Table 3

\section{POOLED UNBUNDLING SHARE AND SCOPE MODELS: 1982, 1987, 1992, 1997, AND 2002 CROSS SECTIONS $(n=14,491)$}

Estimated Coefficient / (Robust Std, Error)

\begin{tabular}{|c|c|c|c|}
\hline Variable & $\begin{array}{c}\text { (1) } \\
\text { Unbundling } \\
\text { Share } \\
\text { (Regression) }\end{array}$ & $\begin{array}{c}\text { (2) } \\
\text { Unbundling } \\
\text { Share } \\
\text { (Regression) }\end{array}$ & $\begin{array}{l}\text { (3) } \\
\text { Scope } \\
\text { (Ordered } \\
\text { Probit) }\end{array}$ \\
\hline Intercept & $\begin{array}{l}-.065^{\mathrm{d}} \\
(.019)\end{array}$ & $\begin{array}{l}.170^{\mathrm{d}} \\
(.018)\end{array}$ & \\
\hline LINC & $\begin{array}{l}.081^{\mathrm{d}} \\
(.003)\end{array}$ & $\begin{array}{l}.112^{\mathrm{d}} \\
(.003)\end{array}$ & $\begin{array}{r}.361^{\mathrm{d}} \\
(.011)\end{array}$ \\
\hline SGUD & $\begin{array}{l}-.018^{b} \\
(.009)\end{array}$ & $\begin{array}{l}-.026^{\mathrm{c}} \\
(.009)\end{array}$ & $\begin{array}{l}-.100^{c} \\
(.035)\end{array}$ \\
\hline SCPS & $\begin{array}{l}.093^{\mathrm{d}} \\
(.002)\end{array}$ & ---- & ---- \\
\hline LEST & $\begin{array}{l}-.029^{d} \\
(.004)\end{array}$ & $\begin{array}{l}-.039^{\mathrm{d}} \\
(.004)\end{array}$ & $\begin{array}{l}-.117^{\mathrm{d}} \\
(.018)\end{array}$ \\
\hline $\mathrm{HCD}$ & $\begin{array}{r}.020^{\mathrm{b}} \\
(.012)\end{array}$ & $\begin{array}{l}-.006 \\
(.012)\end{array}$ & $\begin{array}{l}-.311^{\mathrm{d}} \\
(.051)\end{array}$ \\
\hline LAGE & $\begin{array}{l}-.010^{b} \\
(.004)\end{array}$ & $\begin{array}{l}-.013^{\mathrm{d}} \\
(.004)\end{array}$ & $\begin{array}{l}-.032^{b} \\
(.014)\end{array}$ \\
\hline BRDD & $\begin{array}{l}-.006 \\
(.006)\end{array}$ & $\begin{array}{l}.005 \\
(.007)\end{array}$ & $\begin{array}{l}.137^{d} \\
(.026)\end{array}$ \\
\hline D1987 & $\begin{array}{l}.119^{d} \\
(.011)\end{array}$ & $\begin{array}{l}.111^{\mathrm{d}} \\
(.011)\end{array}$ & $\begin{array}{l}-.078^{\mathrm{a}} \\
(.045)\end{array}$ \\
\hline D1992 & $\begin{array}{r}.200^{\mathrm{d}} \\
(.016)\end{array}$ & $\begin{array}{c}.173^{\mathrm{d}} \\
(.017)\end{array}$ & $\begin{array}{l}-.300^{\mathrm{d}} \\
(.063)\end{array}$ \\
\hline D1997 & $\begin{array}{l}.446^{\mathrm{d}} \\
(.029)\end{array}$ & $\begin{array}{l}.428^{\mathrm{d}} \\
(.029)\end{array}$ & $\begin{array}{l}-.171^{\mathrm{a}} \\
(.103)\end{array}$ \\
\hline D2002 & $\begin{array}{l}.369^{\mathrm{d}} \\
(.035)\end{array}$ & $\begin{array}{r}.336^{\mathrm{d}} \\
(.035)\end{array}$ & $\begin{array}{l}-.390^{c} \\
(.127)\end{array}$ \\
\hline LMBL & $\begin{array}{l}-.055^{\mathrm{d}} \\
(.006)\end{array}$ & $\begin{array}{l}-.070^{\mathrm{d}} \\
(.007)\end{array}$ & $\begin{array}{l}-.170^{\mathrm{d}} \\
(.024)\end{array}$ \\
\hline MPI*LMBL & $\begin{array}{l}-.023^{d} \\
(.006)\end{array}$ & $\begin{array}{l}-.026^{\mathrm{d}} \\
(.006)\end{array}$ & $\begin{array}{l}-.040^{\mathrm{a}} \\
(.127)\end{array}$ \\
\hline SEE & .271 & .286 & NA \\
\hline $\mathrm{R}^{2}$ (adj.) & .321 & .245 & NA \\
\hline $\begin{array}{l}\text { Wald Chi Sq. } \\
(\mathrm{df}=12)\end{array}$ & NA & NA & $1603.37^{\mathrm{d}}$ \\
\hline Pseudo $\mathrm{R}^{2}$ & NA & NA & .045 \\
\hline
\end{tabular}

${ }^{\mathrm{a}} \mathrm{p} .<.10,{ }^{\mathrm{b}} \mathrm{p}<. .05,{ }^{\mathrm{c}} \mathrm{p}<.01,{ }^{\mathrm{d}} \mathrm{p}<.001$ 
Figure 1 Media Price Index and GDP Implicit Price Deflator: 1977-2002

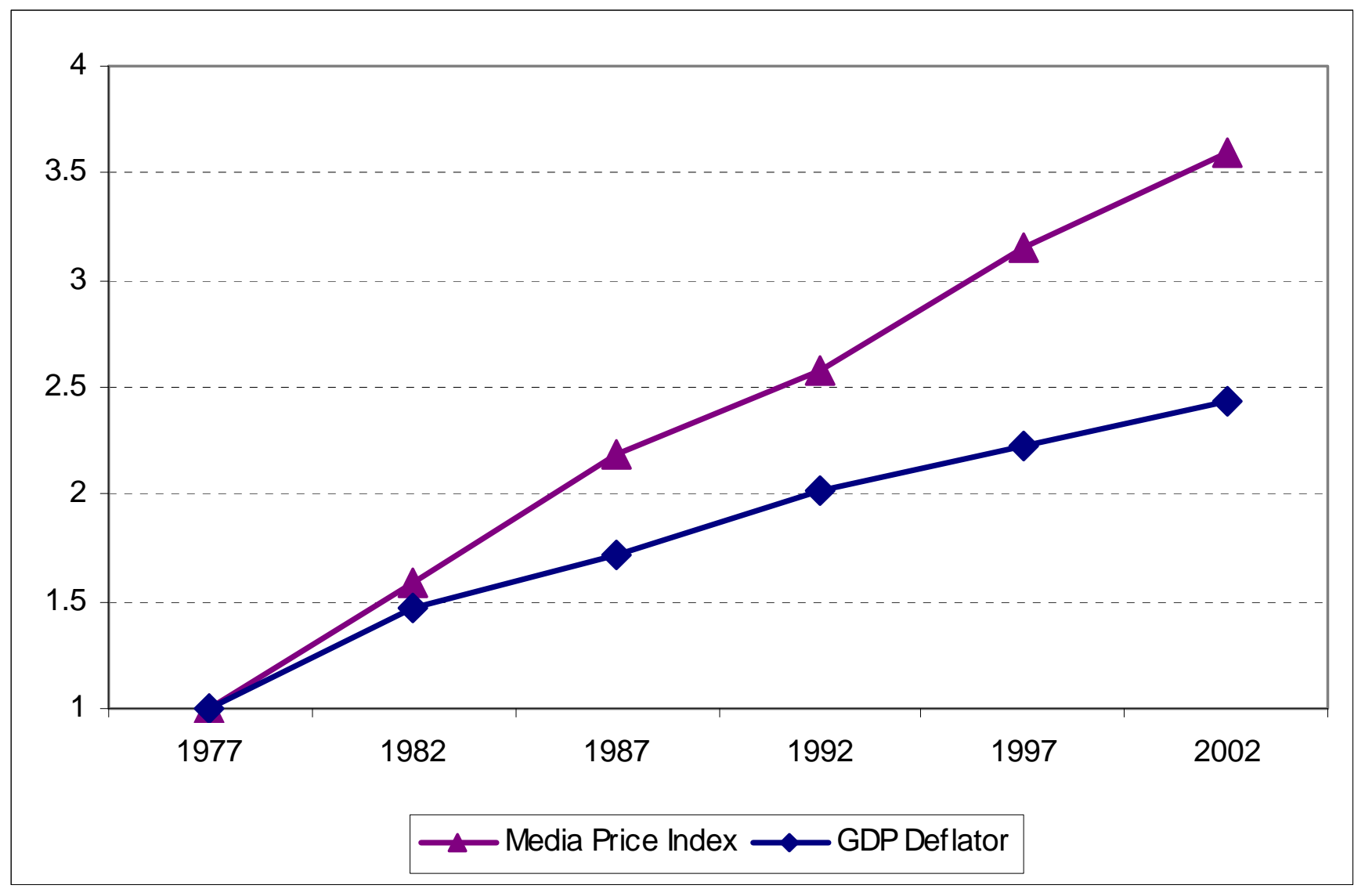


Figure 2: Unbundling Shares, 1977—2002

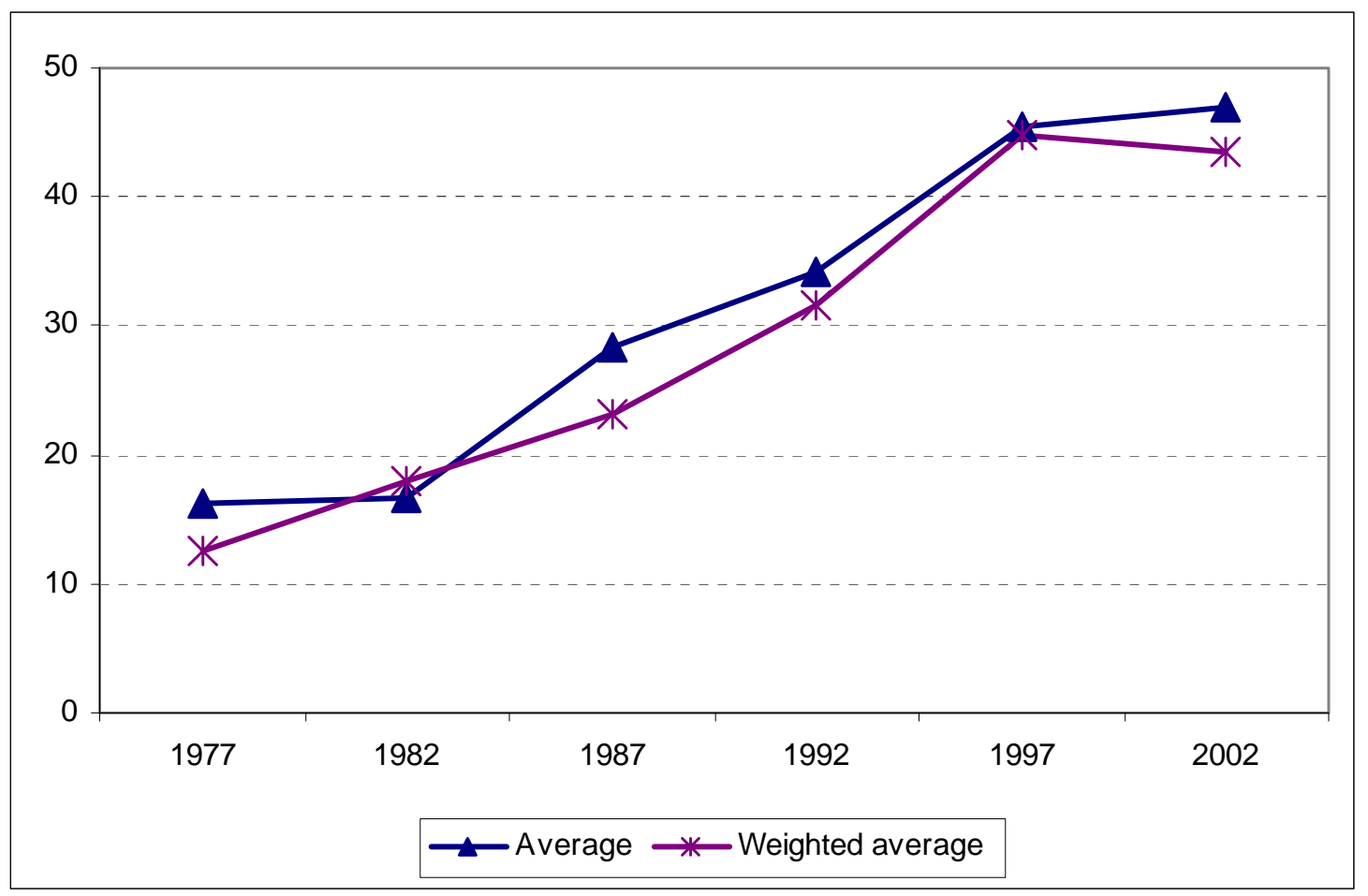


Table A1

SOURCES OF AGENCY INCOME: 1977-1997 ${ }^{1}$

\begin{tabular}{|c|c|c|c|c|c|c|}
\hline & 1977 & 1982 & 1987 & 1992 & 1997 & 2002 \\
\hline \multicolumn{7}{|l|}{$\begin{array}{l}\text { Share of Total } \\
\text { Agency Income (\%) }\end{array}$} \\
\hline Media Commissions & 58.55 & 59.42 & 61.30 & 54.17 & 45.95 & n.a. \\
\hline $\begin{array}{l}\text { Markups on Purchased } \\
\text { Advertising Materials } \\
\text { \& Services }\end{array}$ & 11.77 & 16.19 & 15.82 & 15.81 & 12.98 & n.a. \\
\hline Fees for Services & 24.11 & 20.62 & 19.82 & 24.56 & 26.52 & n.a. \\
\hline $\begin{array}{l}\text { Public Relations } \\
\text { Services }\end{array}$ & 2.69 & 1.52 & 1.48 & 1.44 & 1.99 & n.a. \\
\hline All Other Services & 2.88 & 2.25 & 1.58 & 4.02 & 12.56 & n.a. \\
\hline Total & 100.00 & 100.00 & 100.00 & 100.00 & 100.00 & n.a. \\
\hline $\begin{array}{l}\text { Tot. Agency Income } \\
\text { (Current \$ Millions) }\end{array}$ & $3,168.560$ & $5,919.826$ & $10,213.00$ & $13,607.846$ & $16,871.520$ & $21,103.772$ \\
\hline \multicolumn{7}{|l|}{$\begin{array}{l}\text { Share of Total } \\
\text { Agency Billings (\%) }\end{array}$} \\
\hline Media & 84.78 & 83.95 & 84.48 & 80.38 & 79.29 & 72.58 \\
\hline $\begin{array}{l}\text { Adv. Materials \& } \\
\text { Services }\end{array}$ & 15.22 & 16.05 & 15.52 & 19.62 & 20.71 & 27.42 \\
\hline Total & 100.00 & 100.00 & 100.00 & 100.00 & 100.00 & 100.00 \\
\hline $\begin{array}{l}\text { Total Agency Billings } \\
\text { (Current \$ Millions) }\end{array}$ & $15,453.080$ & $30,115.432$ & $52,328.000$ & $69,586.730$ & $89,061.326$ & $85,282.793$ \\
\hline \multicolumn{7}{|l|}{$\begin{array}{l}\text { Commissions \& } \\
\text { Markups }\end{array}$} \\
\hline $\begin{array}{l}\text { Media Commissions as } \\
\mathrm{a} \\
\% \text { of Media Billings }\end{array}$ & 14.13 & 13.92 & 14.16 & 13.18 & 10.98 & n.a. \\
\hline $\begin{array}{l}\text { Markups on Purchases } \\
\text { of } \\
\text { Adv. Materials \& } \\
\text { Services } \\
\text { As a \% of Billings for } \\
\text { Same }\end{array}$ & 15.84 & 19.83 & 19.90 & 18.39 & 11.88 & n.a. \\
\hline $\begin{array}{l}\text { No. of Agencies } \\
\text { (Establish- } \\
\text { ments with Payroll) }\end{array}$ & 8,089 & 9,668 & 12,335 & 13,879 & 13,390 & 12,489 \\
\hline
\end{tabular}

${ }^{1}$ 1977-92: SIC 7311; 1997-2002: NAICS 54181.

Sources: Compiled from data reported in Sources of Receipts or Revenues, Census of Service Industries, (1977-92) and 1997 Economic Census, Establishment and Firm Size, Professional, Scientific and Technical Services; and Product Lines: 2002, 2002Economic Census, Professional, Scientific, and Technical Services. 
Table A2

WEIGHTED MEAN SHARE OF AGENCY INCOME BY SOURCES OF INCOME

Weighted Mean Share of Agency Income (Standard Deviation)

\begin{tabular}{|c|c|c|c|c|c|}
\hline $\begin{array}{l}\text { Census } \\
\text { Year }^{\mathrm{a}}\end{array}$ & $\begin{array}{l}\text { No. of Agency } \\
\text { Establishments }\end{array}$ & $\begin{array}{l}\text { Commissions on } \\
\text { Media Purchases } \\
\text { Billed to Clients }\end{array}$ & $\begin{array}{l}\text { Markups on Costs } \\
\text { of Materials \& } \\
\text { Services Used on } \\
\text { Client Accounts }\end{array}$ & $\begin{array}{l}\text { Fee Income. for } \\
\text { Services Not } \\
\text { covered by } \\
\text { (1) or (2) }\end{array}$ & $\begin{array}{l}\text { Income from } \\
\text { all other } \\
\text { Unbundled } \\
\text { Services) }\end{array}$ \\
\hline & & (1) & (2) & (3) & (4) \\
\hline 1977 & 2439 & $\begin{array}{c}0.6971 \\
(0.2319) \\
\end{array}$ & $\begin{array}{c}0.1770 \\
(0.1647) \\
\end{array}$ & $\begin{array}{c}0.0937 \\
(0.1441) \\
\end{array}$ & $\begin{array}{c}0.0322 \\
(0.0086) \\
\end{array}$ \\
\hline 1982 & 2385 & $\begin{array}{c}0.6690 \\
(0.2172) \\
\end{array}$ & $\begin{array}{c}0.1521 \\
(0.1634) \\
\end{array}$ & $\begin{array}{c}0.1445 \\
(0.1335) \\
\end{array}$ & $\begin{array}{c}0.0344 \\
(0.0776) \\
\end{array}$ \\
\hline 1987 & 3941 & $\begin{array}{c}0.6209 \\
(0.3159) \\
\end{array}$ & $\begin{array}{c}0.1486 \\
(0.1999) \\
\end{array}$ & $\begin{array}{c}0.2018 \\
(0.2451) \\
\end{array}$ & $\begin{array}{c}0.0287 \\
(0.0753) \\
\end{array}$ \\
\hline 1992 & 5064 & $\begin{array}{c}0.5267 \\
(0.3306)\end{array}$ & $\begin{array}{c}0.1566 \\
(0.2046)\end{array}$ & $\begin{array}{c}0.2565 \\
(0.2886)\end{array}$ & $\begin{array}{c}0.0602 \\
(0.1574) \\
\end{array}$ \\
\hline 1997 & 1876 & $\begin{array}{c}0.4321 \\
(0.3567) \\
\end{array}$ & $\begin{array}{c}0.1210 \\
(0.1999) \\
\end{array}$ & $\begin{array}{c}0.3251 \\
(0.3250) \\
\end{array}$ & $\begin{array}{c}0.1218 \\
(0.2203) \\
\end{array}$ \\
\hline 2002 & 1225 & $\begin{array}{c}0.2949 \\
(0.3339) \\
\end{array}$ & $\begin{array}{c}0.2699 \\
(0.3355) \\
\end{array}$ & $\begin{array}{c}0.3084 \\
(0.3684) \\
\end{array}$ & $\begin{array}{c}0.1804 \\
(0.2746) \\
\end{array}$ \\
\hline
\end{tabular}

${ }^{a}$ 1977-1992, SIC 7311; 1997-02, NAICS 54181. 


\section{REFERENCES}

Achenbaum, Alvin A. (1989), "Compensation Philosophy: The Client View," Negotiating Agency Compensation. New York: American Association of Advertising Agencies, 25-36.

Adams, Williams J.; Yellen, Janet L. (1976) "Commodity Bundling and the Burden of Monopoly," Quarterly Journal of Economics, 90, 475-498.

American Association of Advertising Agencies (1935), "Analysis and Criticism of 'Advertising Agency Compensation: Theory, Law, Practice,"” New York.

York. (1979), “A Practical Solution to Client-Agency Account Conflicts,” July, New York. (1997), "Longevity of Accounts in the Advertising Agency Business, New

Anderson, Arthur A. (1999), “Clout on a Part of Media Buyer's Value," Advertising Age, 70 (April 5), 26.

Arzaghi, Mohammed (2005a), "Quality Sorting and Networking: Evidence from the Advertising Agency Industry," Working Paper 05-16, Center for Economic Studies, U.S. Bureau of the Census, October.

(2005b), “A Model of Knowledge Sharing and Network Formation among Advertising Agencies," unpublished paper available at http//www.nber.org arzghim/papers.htm.

Bagwell, Kyle (2007), "The Economic Analysis of Advertising," Chapter 28 in M. Armstrong and R. H. Porter, Eds., Handbook of Industrial Organization, Vol. 3. New York: Elsevier, 1703-1844.

Baron, David P. and Besanko, David (1992), "Information, Control, and Organizational Structure," Journal of Economics \& Management Strategy, 1, 237-275.

Baron, David P.; Besanko, David (1999), "Informational Alliances," The Review of Economic Studies, 66(4), 743-768.

Baumol, William J., J. D.Panzar, and Robert D. Willig (1988), Contestable Markets and the Theory of Industry Structure, Rev. Ed. New York: Harcourt Brace Jovanovich.

Beals, David (2007), Trends in Agency Compensation, Fourteenth Ed. New York: Association of National Advertisers.

Blank, David M. (1962). "Cyclical Behavior of National Advertising," Journal of Business, 35 (January), 14-27. 
Bloede, Victor G. (1983), “The Full-Service Advertising Agency.” New York: American Association of Advertising Agencies.

Bresnahan, Timothy F. (1982), “The Oligopoly Solution Is Identified,” Economic Letters, $10,87-92$.

Broschak, Joesph P. (2004), "Manages' Mobility and Market Interface: The Effect of Managers' Career Mobility on the Dissolution of Market Ties,' Administrative Science Quarterly, 49 (December), 608-40.

Carlton, Dennis W. and Michael Waldman (2002), "The Strategic Use of Tying to Preserve and Create Market Power in Evolving Industries," RAND Journal of Economics, 33 (2), 194-220.

Chura, Hillary and Laurel Wentz (2004), "Media Agencies Struggle to Manage Client Conflicts," Advertising Age, 75 (April 12), 16.

Davis, Steven J. and Kevin M. Murphy (2000), “A Competitive Perspective on Internet Explorer," American Economic Review, 90(2), 184-187.

Dilenschneider, Bob (1992), "Clients Now Cherry-Picking Creativity," Advertising Age, 63 (March 2), 16.

Drexler, Michael D. (2002), "Unraveling the Media Myth," Advertising Age, 73 (November 11), 22.

Duboff, Robert S. (2007), ROI for Marketing: Balancing Accountability with Long-Term Needs. New York: Association of National Advertisers.

Eaton, B. Curtis and S.Q. Lemeche (1991), "The Geometry of Supply, Demand, and Competitive Market Structure with Economies of Scope," American Economic Review, 82 (September), 901-11.

Escobar, J. Francisco (2005), Marketing Communications Procurement: Best Practices. New York: Association of National Advertisers.

Evans, David S. and Michael Salinger (2005), "Why Do Firms Bundle and Tie? Evidence from Competitive Markets and Implications for Tying Law," Yale Journal on Regulation, 22 (Winter), 37-89.

(2008), "The Role of Cost in Determining When Firms Offer Bundles," Journal of Industrial Economics, 56 (March), 143-168. (2008), "The Economics of the Online Advertising Industry," unpublished paper, May. Available at http://ssrn.com/abstract=1086473. 
Fine, Lauren Rich, Julien Roch, Hester Chang, Karl Choi, Sara Gubins, Stacy Fleck, and Heather Richey (2005), "Advertising \& Marketing Services: Global Ad Primer," Global Securities Research \& Economics Group, Merrill Lynch, New York, June 22.

Fitzgerald, Kate (2004), “Conflict Issues Grow Murkier," Advertising Age, 75 (February 9), S12 and S19.

Frey, Albert W. and Kenneth R. Davis, (1958), The Advertising Industry. New York: Association of National Advertisers.

Gilbert, Richard J. (1989), "Mobility Barriers and the Value of Incumbency," Chapt. 8 in Handbook of Industrial Organization, Vol. 1, Richard Schmalensee and Robert Willig, Eds. New York: North Holland, 475-535.

Gilbert, Richard; Riordon, Michael (1995), "Regulating complementary products: A comparative institutional analysis," RAND Journal of Economics, 26(2) 243-256.

Gleason, Mark (1995), "Role of Performance Gains in Agency Pay," Advertising Age, 66, 4.

Gleason, Mark and Laura Petrecca (1996), "Split Decisions Grow as Advertisers Seek Edge," Advertising Age, 67 (November 11), 1.20 and 22.

Goldring, Norman (1986), "Future Lies in Place Called 'Media," Advertising Age, 57 (November 3), 63-64.

Greene, William H. [2003]. Econometric Analysis, $5^{\text {th }}$ Edition. Upper Saddle River, NJ: Pearson Education, Inc.

Gross, Irving (1972), “The Creative Aspects of Advertising” Sloan Management Review, 14 (Fall), 83-109.

Haase, Albert E. (1933), “An Analysis of a Report Called 'Advertising Agency Compensation." New York: Association of National Advertisers. , Lawrence C. Lockley, and Issac W. Diggest (1934), “Advertising Agency Compensation: Theory, Law, Practice.” New York: Association of National Advertisers.

Hameroff, Eugene J. (1998), The Advertising Agency Business: The Complete Manual for Management \& Operation. New York: McGraw-Hill.

Heckman, James (1976), “The Common Structure of Statistical Models of Truncation, Sample Selection, and Limited Dependent Variables and a Simple Estimator for such Models," Annals of Economic and Social Measurement, 5, 475-492. 
Heckman, James (1979), "Sample Selection Bias as a Specification Error," Econometrica, 47, 153-161.

Holland, Donald R. (1981), “The Great Tradeoff,” Advertising Age, 52 (July 6), 41-42.

Hovland, Michael A. and Jason G. Gauthier (2006), "Procedural History of the 2002 Economic Census.” Washington, D.C.: U.S. Census Bureau.

Horsky, Sharon (2006), "The Changing Architecture of Advertising Agencies," Marketing Science, 25 (July-August), 367-383.

Jarmin, Ron and Javier Miranda (2002), “The Longitudinal Business Database," Center for Economic Studies, working paper CES-WP-02-17, available at www.ces.census.gov.

Johnson, Bradley (2005), "Interpublic Gets Less than 1.5 Fee on Measured Media," Accessed at http://adage.com/news.cms?newsld=44547.

Jung, Chulho and Barry J. Seldon (1995), "The Degree of Competition in the Advertising Industry," Review of Industrial Organization, 10, 41-52.

King, Charles, Alvin J. Silk and Niels Ketelhohn (2003), "Knowledge Spillovers and Growth in the Disagglomeration of the U.S. Advertising-Agency Industry," Journal of Economics \& Management Strategy, 12 (Fall), 327-362.

Loomis, Carol J. (1972), “Those Throbing Headaches on Madison Avenue," Fortune, 85 (February), 103-106 and $197 \mathrm{ff}$.

Mandese, Joe and Melanie Wells (1992), "More Shops Create Seperate Media Units," Advertising Age, 63 (November 16), 41.

(1994), "Full-Service Shops Lured to Media-Only Acconts," Advertising Age, 65 (January 31), 8.

(1995), “Losing Momentum,” Advertising Age, 66 (April 10), 1 and 8.

(2002), "Consolidation or Consolation? Madison Avenue's Big Get Bigger," $\overline{A D M A P}$, Issue 450 (July/August), 8.

McAfee, R. Preston, John McMillan, and Michael D. Whinston (1989), "Multiproduct Monopoly, Commodity Bundling, and Correlation of Values," Quarterly Journal of Economics, 104 (2) 371-384.

McCellan Steve (2008), “Agency Overhaul: Why Media Shops are Reorganizing to Offer Broader Marketing Services," Adweek.com (June 16).

McDonald, H.E. (1989), “The Price of the Hot Dog Is Too High,” Negotiating Agency Compensation. New York: American Association of Advertising Agencies, 15-22. 
McNamara, Jay (1990), Advertising Agency Management. Homewood, IL: Dow JonesIrwin.

McVeigh, Robert A. (1979), "BBDO's Efficiency Fee Incentive Plan," Agency

Compensation: A Guidebook. New York: Association of National Advertisers, 89-96.

Millman, Nancy (1988), Emperors of Adland. New York: Warner Books.

Neff, Jack (2005), "P\&G Moves Gillette's \$800 Million Ad Buying Account," AdAge.com (October 5).

Paff, Fred (1987), "Media for Hire,” Marketing \& Media Decisions, 22 (October), 34-40.

Palfrey, Thomas R. (1983), "Bundling Decisions by a Multiproduct Monopolist with Incomplete Information," Econometrica, 51(2), 463-483.

Pope, Daniel (1983), The Making of Modern Advertising. New York: Basic Books.

Posner, Richard A. (1979), "The Chicago School of Antitrust Analysis," University of Pennsylvania Law Review, 127(4), 925-948.

Pulver, Robert E. (1979), “Advertising Services: Full-Service Agency or a La Carte, or In-House?” New York: Association of National Advertisers.

Reilly, William J. (1931), Effects of the Advertising Agency Compensation System. New York: published by author.

Reinhard, Keith (2001), “Keep It Together,” Advertising Age, 72 (September 10), 26.

Rigg, Cynthia (1990), "Buying Gets Hot,” Advertising Age, 61 (November 12), 24.

Salinger, Michael A. (1995), “A Graphical Analysis of Bundling," Journal of Business, 68 (January), 85-98.

Sampey, Kathleen (2005), "So Few Choice for Clients, So Many Account Conflicts," ADWEEK, (June 6), 12.

Schmalensee, Richard L. (1977), "Using the H-Index of Concentration with Published Data," Review of Economics and Statistics, 59 (May), 186-193.

Schmalensee, Richard (1982), "Commodity Bundling by Single-Product Monopolies," Journal of Law and Economics, 25(1), 67-71.

Schmalensee, Richard L., Alvin J. Silk, and Robert Bojanek (1983), "The Impact of Scale and Media Mix on Advertising Agency Costs," Journal of Business, 56 (October), 453475 . 
Schmalensee, Richard (1984), "Gaussian Demand and Commodity Bundling," Journal of Business, 57, 58-73.

Silk, Alvin J. and Ernst R. Berndt, (1993), "Scale and Scope Effects on Advertising Agency Costs," Marketing Science, 12 (Winter), 53-72.

(1994), "Costs, Institutional Mobility Barriers, and Market Structure: Advertising Agencies as Multiproduct Firms," Journal of Economics \& Management Strategy, 3 (Fall), 437-480.

(2004), "Holding Company Cost Economies in the Global Advertising and Marketing Services Business," Review of Marketing Science, 2 (Article 5). Available at http://www.bepress.com/romsjournal.

Silk, Alvin J. and Charles King III (2008), "Concentration in the U.S. Advertising and Marketing Services Industry: Myth vs. Reality," unpublished working paper, July.

Spake, Deborah F., Giles D’Souza, Tammy Neal Crutchfield, and Robert M.Morgan (1999), "Advertising Agency Compensation: An Agency Theory Explanation," Journal of Advertising, 28 (Fall), 53-72.

Spector, David (2007), “Bundling, Tying, and Collusion," International Journal of Industrial Organization, 25 (June), 575-581.

Stigler, George J. (1968), “A Note on Block Booking,” in George J. Stigler, ed., The Organization of Industries, Homewood, IL: Irwin, 165-170.

Varian, Hal R. (1989), "Price Discrimination," Chapt. 8 in Handbook of Industrial Organization, Vol. 1, Richard Schmalensee and Robert Willig, Eds. New York: North Holland, 597-654..

Whinston, Michael D. (1990), "Tying, Foreclosure, and Exclusion," American Economic Review, 80(4), 837-859.

Weilbacher, William M. (1991), Choosing \& Working with Your Advertising Agency. Chicago: NTC Books,

Wilson, Raymond E., Franklin J. Hennessy, and Shelby H. Page (1969), "The Shell Fee Arrangement with Ogilvy and Mather and Kenyon and Eckhardt," Fee Methods of Agency Compensation. New York: Association of National Advertisers, 77-87.

Wooldridge, Jeffrey M. (2000), Introduction to Econometrics.Cincinatti, OH: SouthWestern.

Young, James W. (1933), Advertising Agency Compensation. Chicago: University of Chicago Press. 